\title{
PŮSOBENÍ JAROSLAVA BIDLA A MILADY PAULOVÉ V PRAŽSKÉ UNIVERZITNÍ EXTENZI
}

\author{
DANIELA BRÁDLEROVÁ - MAREK ĎURČANSKÝ
}

\section{THE WORK OF JAROSLAV BIDLO AND MILADA PAULOVÁ IN THE PRAGUE UNIVERSITY 'EXTENSION'}

Like many other universities across Europe, the Czech Charles-Ferdinand University in Prague (later Charles University), too, since the end of the nineteenth century tried to reach wider strata of society using lectures intended for the broad public, so-called 'extensions'. These activities importantly included several representatives of historical Slavic studies, especially Jaroslav Bidlo and his student Milada Paulová. This study focuses on the period during which Bidlo, in 1921-1931, served as president of the Prague committee for organising lectures for the broad public, the 'Extension of Prague Universities', while Paulová helped as a secretary of this institution (1921-1935).

Keywords: Charles University in Prague - popular lectures - Extension of Prague Universities - Jaroslav Bidlo Milada Paulová - 20th century

DOI: $10.14712 / 23365730.2021 .19$

Ve studiích, publikovaných nedávno na stránkách časopisu AUC-HUCP, bylo analyzováno působení Jaroslava Bidla a Milady Paulové na Univerzitě Karlově, a to především s ohledem na rozvoj historické slavistiky. ${ }^{1}$ Pouze zmíněny byly jejich aktivity v rámci univerzitní extenze, resp. Výboru pro lidovýchovné přednášky českých vysokých škol pražských, jak zněl přesný název této organizace ještě na počátku 20. let 20. století. ${ }^{2}$ Už dříve se ale používal také neoficiální název „extense“ odkazující na anglosaský původ tohoto zajímavého fenoménu. Jeho institucionalizovaná česká, resp. československá varianta existující od konce 19. do poloviny 20. století, kdy byla transformována do Společnosti

1 Daniela Brádlerová, Milada Paulová a pražská univerzita: historická slavistika, Acta Universitatis Carolinae - Historia Universitatis Carolinae Pragensis (dále AUC-HUCP) 59/1, 2019, s. 97-147; Marek ĎuRČANSKÝ, Jaroslav Bidlo a pražská univerzita: $k$ počátkưm české historické slavistiky, tamtéž, s. 53-95.

2 K terminologii srov. velmi trefnou poznámku: František X. HALAs, Extenze československých vysokých škol a brněnská univerzita, Sborník prací Filozofické fakulty brněnské univerzity, C 28, 1981, s. 77-94, zde s. 78, pozn. 2. Pro praktické potřeby této studie je třeba uvést, že pokud je užívána podoba termínu „extenze“, je tím míněn typ organizace obecně (př́ípadně s příslušnou místní specifikací, např̀. „brněnská extenze“). Forma „Extenze“ v jednotném čísle označuje výhradně pražskou organizaci, nesoucí až do r. 1926 oficiální název „Výbor pro pořádání lidovýchovných přednášek českých vysokých škol pražských“. Forma „Extenze“v množném čísle (!) označuje společnou organizaci českých, moravských a slovenských vysokých škol (formálně pražských, brněnských a bratislavských, což není přesné, protože k pražské extenzi se hlásila např. i příbramská báňská akademie). 
pro šíření politických znalostí, ${ }^{3}$ je př́iležitostně objektem odborného zájmu. Obvykle je ovšem veden spíše souvislostmi s konkrétní osobností ${ }^{4}$ nebo nějakou dílčí otázkou ${ }^{5}$. To je ostatně také cílem následujícího textu - ve 20. letech byl předsedou intenzivně se rozvíjející pražské extenze (spolupracující i s nově vzniklými paralelními místními extenzemi v Brně a Bratislavě) Jaroslav Bidlo a funkci tajemnice ${ }^{6}$ plnila Milada Paulová. Téma souvisí s působením obou zakladatelských osobností české historické slavistiky na Univerzitě Karlově, dosah jejich činnosti byl ale v tomto ohledu širší - zahrnoval široké laické vrstvy zájemců o přenos vědeckých poznatků a popularizaci nejnovějších výsledků světové vědy. V této souvislosti byli Bidlo a Paulová součástí široké sítě propojující československé vysoké školy (s výjimkou škol německých a od poloviny 20. let duchovních fakult) s dalšími osvětovými a kulturními institucemi na celostátní i lokální úrovni. Jejich role v tomto dění byla ale mnohem více než průměrná.

\section{Poznámka o pramenech a literatuře}

Vzhledem k tomu, že se v poslední době v praxi Archivu UK opakovaně objevovaly badatelské dotazy na archiválie $\mathrm{k}$ dějinám univerzitních extenzí, považujeme za užitečné připojit několik základních informací o pramenech a literatuře. Pro rekonstrukci účasti české univerzity na ,lidovýchovném hnuti'“ jsou vedle př́slušných úředních tisků a bilancujících brožur klíčovým pramenem písemnosti uložené ve fondu Akademický senát Univerzity Karlovy, které pokrývají v zásadě celou dobu existence univerzitních extenzí. ${ }^{7}$ Jejich výpovědní hodnota je ovšem širší, pocházejí totiž převážně z působnosti výboru, který zahrnoval obě české pražské vysoké školy (tedy také ČVUT) a od počátku 20. let 20. století úzce spolupracoval s brněnským a bratislavským výborem, do jejichž gesce spadalo území Moravy a Slezska, resp. Slovenska. Archiválie z meziválečného období jsou o to důležitější, že se písemnosti brněnské extenze $\mathrm{z}$ této doby dochovaly jen velmi torzovitě. ${ }^{8}$ Vzhledem ke značné vázanosti extenzí na senáty př́slušných vysokých škol, jsou také v př́padě Akademického senátu České univerzity Karlo-Ferdinandovy (resp. Univerzity Karlovy) relevantní protokoly z jeho zasedání, obsahující mimo jiné údaje o volbě funkcionářu Extenze. ${ }^{9}$ Samostatný fond „Extenze vysokých škol“ uložený v Archivu UK sestává pouze z jediného kartonu s neuspořádanou registraturou pražské extenze z období konce její existence (1951), ovšem včetně zajímavé korespondence a ilustračního materiálu (plakáty, pozvánky).

3 Doubravka OLšÁKovÁ, Věda jde k lidu! Československá společnost pro širení politických znalostí a popularizace věd v Československu ve 20. století, Praha 2014.

4 Jaroslav HrduičKa, Historik a diplomat Vlastimil Kybal, Praha 2020, s. 125-128.

5 F. X. Halas, Extenze československých vysokých škol.

6 Termín „sekretářka“, který byl uživán v souvisejících dobových pramenech 20. a 30. let i Miladou Paulovou samotnou, je třeba vnímat v dobovém kontextu a se zohledněním reálné náplně funkce, tedy v dnešním významu tajemník/tajemnice. Také Vlastimil Kybal, její dlouholetý předchůdce na tomto postu, byl označován jako sekretár.

7 Archiv Univerzity Karlovy (dále AUK), fond Akademický senát Univerzity Karlovy (dále AS UK), kart. 222, i. č. 3350-3352; tamtéž, kart. 230, i. č. 3384-3385.

8 F. X. Halas, Extenze, s. 79n.

9 AUK, AS UK, kart. 41-45. 
Vznik a první léta univerzitních extenzí v Praze a v Brně byly už vícekrát předmětem různých dobových pojednání, $v$ nichž především samotní aktéři své působení reflektovali do velké míry v souvislosti s dílčími výročími nebo v zájmu představení celkové problematiky extenzí širší veřejnosti. ${ }^{10}$ Cenné jsou vzpomínkové texty, pocházející od osobností, které se v problematice lidovýchovných přednášek významně angažovaly, at’ už máme na mysli prvního sekretáŕe pražské extenze Vlastimila Kybala, nebo prvního předsedu brněnské extenze (a původně profesora pražské filozofické fakulty) Vladimíra Nováka. ${ }^{11} \mathrm{Z}$ vydané korespondence je nepochybně nejobsažnější ta, kterou mezi sebou vedli oba protagonisté předkládané studie, pro jejíž účely byla také v rámci možností využita. ${ }^{12}$ Úřední prameny tato korespondence $\mathrm{v}$ řadě ohledů doplňuje, ale má oproti nim mnohem méně soustavný charakter - o záležitostech Extenze se totiž J. Bidlo s M. Paulovou zjevně písemně domlouvali především $\mathrm{v}$ př́padech, kdy nebylo možné záležitosti vyřešit podstatně operativněji při osobním setkání nebo telefonicky. $\mathrm{V}$ rámci nevydané korespondence byla provedená heuristika zaměřena hlavně na členy výboru pražské extenze. $Z$ dalších typů egodokumentů se teoreticky nabízejí hlavně deníkové texty, prakticky však jsou z relevantních dokumentů této povahy nejspíše $\mathrm{k}$ dispozici pouze editované deníky Otakara Odložilíka, ${ }^{13}$ který se stal členem výboru $v$ polovině 30 . let.

\section{Pražská univerzitní extenze v českých zemích před vznikem Československa a zapojení J. Bidla do její činnosti}

Počátky univerzitních přednášek pro širokou veřejnost souvisejí s anglosaským univerzitním prostředím, konkrétně s univerzitou v Cambridge na začátku 70. let 19. století. Úspěšný model popularizace vědeckých poznatků a jejich šiření mimo samotné univerzitní posluchárny vycházel vstříc dobovým demokratizačním proudům a rychle pronikl také do dalších evropských zemí a Spojených států amerických. ${ }^{14} \mathrm{~K}$ těmto kořenům celého fenoménu se $\mathrm{v}$ bilancujících textech čeští/českoslovenští představitelé univerzitních extenzí opakovaně vraceli. Zvláště po roce 1918 rovněž takřka bez výjimky zdůrazňovali, že to byl právě pozdější prezident Tomáš Garrigue Masaryk, kdo se v roce 1896 angažoval v př́ipravě lidovýchovných přednášek a po schválení vídeňským ministerstvem kultu a vyučování se stal na jaře 1899 prvním přednášejícím pražské české extenze s přednáškou $O$ vývoji

10 František Drtina, Lidové přednášky universitní, in: týž, University a učitelstvo. Soubor statí, Praha 1932 (=Spisy Františky Drtiny, svazek V), s. 7-28; TÝž, Universitní extense, in: Ottův slovník naučný, díl 26., Praha 1907, s. 196-199; Richard Horna - Jan OPravil - Milada PAulová, Extense československých vysokých škol v Republice československé v třicetiletí 1898-1928, Praha 1928.

11 Vlastimil Kybal, Paméti Vlastimila Kybala, I, edd. Jaroslav HrdičKa - Jan Blahoslav LÁšEK, Chomutov Praha 2012, zvl. s. 134n, 152, 177n, 211n; Vladimír NovÁK, Vzpomínky a paměti (Životopis), Brno 1939, zvl. s. $369-379$.

12 Daniela BrÁdlerová - Jan Hálek (edd.), Jaroslav Bidlo - Milada Paulová. Střet generací? Paméti a vzájemná korespondence zakladatelů české byzantologie a slovanských studií, Praha 2014.

13 Milada SeKyrková (ed.), Otakar Odložilik: Deniky z let 1924-1939, I-II, Praha 2002.

14 Vznik a vývoj univerzitních extenzí v zahraničí a jejich počátek na domácí půdě přehledně shrnul František Drtina, jeden z prvních předsedů pražské extenze. F. DRTINA, Lidové přednášky universitní. 
evropské společnosti v XIX. století. Ústředním motivem v rámci tohoto širokého tématu Masarykova výkladu byla ovšem popularizace vědy a její prostředky. ${ }^{15}$

Vedle Masaryka spočívala tíha přípravy prvních stanov a dalších organizačních záležitostí zejména na estetikovi Otakaru Hostinském, jakožto děkanovi české filozofické fakulty v akademickém roce 1898/1899, a dále pak na chemiku Bohuslavu Raýmanovi a lékaři Josefu Reinsbergovi. Ten se také stal prvním předsedou pražské extenze, následován Otakarem Hostinským (1899/1900), jehož na akademický rok 1900/1901 znovu vystřídal. Další předsedové Extenze už působili ve funkci po delší dobu: František Drtina (1901/1902-1907/1908), František Čáda (1908/1909-1911/1912) a František Počta (od r. 1912/1913). ${ }^{16}$ Jeho nástupcem byl J. Bidlo (podrobněji níže). Prvním sekretářem se stal zoolog Karel Thon (1879-1906), po jehož předčasné smrti spojil svou odbornou kariéru s touto funkcí na delší dobu historik Vlastimil Kybal. Od roku 1908 k pražské extenzi oficiálně přistoupila také technika, jejíž profesoři zde přednášeli jako externisté již v několika předcházejících letech.

V samotné Praze se činnost Extenze brzy stabilizovala do podoby, kdy byly ročně pořádány tři řady ,šestipřednáškových“ kursů (listopad a prosinec, leden a únor, březen a duben). Po organizační stránce situaci ztěžovala skutečnost, že Extenze neměla k dispozici vlastní budovu a místo konání tak muselo být vždy znovu dojednáváno ad hoc. Strmě se zvyšoval počet přednášek konaných na venkově - od několika desítek v r. 1901 po více než sto o dva roky později. Velmi úspěšným počinem byly učitelské kursy, pořádané za účasti několika tisícovek posluchačů vždy v některém z větších měst. Na prahu 1 . světové války tak byla pražská extenze zavedenou institucí v oblasti lidové výchovy a osvěty. ${ }^{17}$

Starší z protagonistů této studie působil v rámci extenze takřka od jejích začátků a zároveň od prvních let své odborné univerzitní kariéry. Ještě než se Jaroslav Bidlo zapojil do činnosti Extenze jako jeden z jejích funkcionářù, získal praktické zkušenosti jako přednášející. Patrně poprvé přednášel tehdejší mladý docent všeobecných dějin v Rakovníce 6. dubna 1902 o Jednotě bratrské na přímé přání předsedy F. Drtiny. ${ }^{18}$ Ten jej zanedlouho kontaktoval (patrně) kvůli přednáškám v Plzni ${ }^{19}$ a na podzim téhož roku také kvůli přednáškám v Brně. ${ }^{20}$

Dále víme, že Bidlo přednášel v rámci Výboru pro pořádání lidových přednášek během XIX. řady (březen-duben 1906), a to v Břevnově na téma Náboženské dějiny české v 16. století a česká emigrace po bitvě bělohorské za účasti 58 posluchačů. ${ }^{21}$ Jednalo se

15 Vladimír Novák, Jak přibližiti vysoké školy lidu, in: Antonín Beer - František Kadeřávek (eds.), Věstník I. řřšského sjezdu československých učitelů vysokých škol, Praha 1922, s. 79-85, zde s. 80.

16 R. Horna - J. Opravil - M. Pauloví, Extense, s. 6n, 15n.

17 Tamtéž, s. 7-10 a tabulky na s. 34-53.

18 „Prosím Vás tedy snažně, byste se obětoval a nejlépe o Jednotě českobratrské slíbil přednášeti. Podmínky znáte: honorár $50 \mathrm{~K}$, cestovné a ubytování. Ráno byste odjel a večer se vrátíte." Masarykův ústav a Archiv Akademie věd ČR (dále MÚA), fond Jaroslav Bidlo (dále fond J. Bidlo), kart. 3, i. č. 133. F. Drtina J. Bidlovi, 24. 2. 1902, Praha.

19 Tamtéź, F. Drtina J. Bidlovi, 23. 5., 1902, Praha.

20 Na lístku napsaném zjevně v chvatu Drtina Bidlovi sděluje: „Milý pane kolego, bud’te bez starosti, celý kurs historický (Pekař - Novotný - Vy) jest odložen o rok, takže teprve v březnu-dubnu 1904 na Vás dojde řada, a tu Vám to asi již bude možno. // Brněnská přednáška je pevně stanovena na $8 / 2$, titul již je nutno znáti. Oznamte jej ihned lístkem mně i na adresu p. František Píša, jednatel vzděl. odboru v Brně (Rudolfova ul.) - chtějí již dáti tisknout plakáty. Syllabus mi pošlete nejdéle do 6/1." Tamtéž, F. Drtina J. Bidlovi, 23. 12. 1902, Praha.

21 Zpráva Výboru pro porádání lidových přednášek C. k. české university Karlo-Ferdinandovy v Praze za léta 1903/4 - 1906/7 (̌̌ada XII. - XXII.), Praha 1908, s. 27. Prostřednictvím Extenze byl Bidlo v roce 1906 osloven 
o šestidílný kurs, který se konal vždy v neděli odpoledne, přičemž se Bidlo dopravoval do Břevnova povozem zajištěným organizátory. Před započetím kursu byl upozorněn, že „s ohledem na místní poměry břevnovské bude nutno výklady poněkud zpopularizovati a více ku všeobecným a zajímavějším stránkám přihližeti “. ${ }^{22}$ Následně se účastnil XXI. řady (únor-březen 1907) přednáškou O Jednotě Česko-Bratrské v Rychnově nad Kněžnou (107 posluchačů) a O Jednotě českobratrské se zvláštním žretelem ke Komenskému v Soběslavi (140 posluchačů). ${ }^{23} \mathrm{~V}$ následujícím roce si na 25 . března vyjednala Zemská jednota soukromých úředníků v Ústí nad Orlicí tutéž přednášku (sekretář Extenze V. Kybal tam posílal sylabus ,loňské rychnovské přednášky o témže předmětě ${ }^{\text {c* }}{ }^{24} \mathrm{~V}$ nabídce pro akademické roky 1912/1913 a 1913/1914 pak figurovaly v části pro Prahu a předměstí Bidlovy kursy Déjiny Slovanstva a Dějiny jednotlivých národů slovanských, v části pro venkov O jednotě českobratrské, Dějiny Slovanstva a Dějiny jednotlivých národi̊ slovanských. ${ }^{25}$ Zájem o ně měl např́iklad libeňský Sokol. ${ }^{26}$

Z Bidlovy písemné pozůstalosti také víme, že byla v létě 1918 v jednání jeho účast na cyklu přednášek v Bat’ových závodech ve Zlíně27 a že jej na jaře 1921 zvali k účasti na -

také Veřejnou čítárnou v Hradci Králové, smluvená přednáška 7. 7. v místní sokolovně k výročí M. Jana Husa byla ale nakonec domluvena mimo rámec Extenze, protože - jak se pořadatelé dozvěděli - ,výbor nepořádá přednášek př́ležitostných“. MÚA, fond J. Bidlo, kart. 9, i. č. 883. Jan Divecký (Veřejná čítárna Palackého v Hradci Králové) J. Bidlovi, 7. 6., 12. 6. a 19. 6. 1906, Hradec Králové.

22 MÚA, fond J. Bidlo, kart. 9, i. č. 884. Karel Thon (Výbor pro pořádání lidových přednášek C. k. České university Karlo-Ferdinandovy) J. Bidlovi, 7. 2. a 20. 2. 1906, Praha.

23 Tamtéž, s. 36, 39. Podrobnosti, které sděloval sekretář Extenze Bidlovi, stojí za obsáhlejší citaci: „1. Jak Vám známo, bude se přednáška rychnovská konati 17. března o 2. hod. odp. v hostinci „U Labutě“ (ne v Nár[odním] Domě). Místním pořadatelem je Akad[emický] spolek Orličan, starosta Alois Dohnálek, t. č. v Rychnově. Podle $§ 4$ Zásad místní pořadatelstvo Vám zaplatí: 1. honorár̆ $40 \mathrm{~K}, 2$. jízdné po dráze, t. j. lístek III. tř̆. osob[ního] vlaku nebo rychlíku, požívá-li přednášející výhody na základě úřední legitimace, jinak lístek II. tř., 3. výlohy za ubytování a stravování v tom př́padě, že je samo pořadatelstvo za Vás na místě neplatí; obyčejně pořadatelé platí tyto výlohy sami hned na místě. - Hned po přednášce bude Vám poslán blanket pro účet, jejž vyplníte a podepíšete, načež kvestura Vám osobně nebo osobě, jež účet přinese, účet zapraví. // 2. Přednáška v Soběslavi bude se konati 24. března o 3 hod. odp. v Národním hostinci. Místní pořadatel: Akad[emický] spolek Štítný (Prokop Novák, místostarosta, t. č. v Soběslavi). Na dráze dostanete slevu na základě úřední své legitimace. Účet podobně jako při Rychnově. // Přednáška v Písku odpadá, protože místní pořadatelstvo (Sokol) ustoupilo Osvět[ovému] svazu, jenž bude sám v Písku pořádati přednášku o Komenském. Omlouvá se proto a prosí, «by nám se strany Vašeho Blahorodí odvolání toto laskavě prominuto bylo». Budou tam pořádati kurs trrípřednáškový doc. Janko, Vavř́nka a Velicha v dubnu - květnu. // Rovněž moje snaha uskutečniti Váš kurs pražský o Rusku XIX. st[oletí] nepotkala se s cílem.“ MÚA, fond J. Bidlo, kart. 5, i. č. 377, V. Kybal J. Bidlovi, 6. 2. 1907, Praha.

24 MÚA, fond J. Bidlo, kart. 5, i. č. 377, V. Kybal J. Bidlovi, s. d. [26. 2. a 29. 2. 1908], Praha.

25 Lidové přednášky českých vysokých škol pražských (Stanovy, zásady a seznam přednášek). Studijni léta 1912-12 a 1913-14, Praha 1913, s. 14 a 22.

26 „Libenský Sokol žádá výboru, aby na podzim v jeho nové budově uspořádal kurs šestipřednáškový a na prvním místě žádá o Váš kurs o dějinách Slovanstva. My jsme tam původně zamýšleli položiti kurs prof. [Aloise] Mrázka, ale prof. M. potřebuje zoologického ústavu ke svým výkladům a Libenští, jak z lístku jejich patrno, žádají o kurs M. až na místě posledním. Dovolujeme si tudíž Vás se otázat, zda byste v Libni přednášel, a to (poněvadž uvedené téma je př́liš široké na šest přednášek) speciální kurs o dějinách např. jižních Slovanů v novější době. Poněvadž program není posud pevně sestaven, musíme si ovšem vyhraditi možnost stanovení hodin a dne podle dispozic místních a rozumí se i podle Vašeho přání.“ MÚA, fond J. Bidlo, kart. 9, i. č. 884, Sekretariát Lidových přednášek českých vysokých škol pražských J. Bidlovi, 5. 7. 1913, Praha.

27 Jednání vedené prostřednictvím V. Kybala patrně nebylo jednoduché. Mladší kolega a sekretář Extenze Bidlovi sděloval, že ,posluchačstvo bude dělnické“ a honoráŕ bude ve výši $60 \mathrm{~K}+$ jízdné a diety. Následně pak upřesňoval: „Velice rád bych Vám oznámil co positivního o přednáškách ve Zlíně, ale bohužel nemáme odtamtud žádných zpráv. Poslal jsem jim před měsícem program, před týdnem jsem urgoval odpověd', ale posud neodpověděli tak ani onak. Také moje úsilí promluvit osobně s p. Bat'ou v Praze minulo se s úspěchem. Ještě se však 
co do programu velmi ambiciózních - přednáškových kurzech spolupořádaných Okresním osvětovým sborem ve východočeských Hořicích. Jejich rámcový název zahrnující přednášky z různých oborů zněl: Světový názor na základě nejnovějších vědecko-filosofických názorů. Snad i proto pořadatelé požádali Bidla o obecněji pojaté téma, než byly jím původně nabízené přednášky z dějin Ruska, jež jinak do budoucna neodmítali. Výsledný název Bidlovy přednášky tak měl znít Historicko-politický vznik dneška a tendence vývoje. Zajímavé jsou další okolnosti zmiňované v korespondenci pořadatelů s Bidlem. Počítalo se s poměrně bohatým doprovodným programem (,výlety, exkurse, divadlo, koncert, společenský večirek") a dokonce i s přípravnou školou „pro návštěvníky s menším vzděláním“ probíhající s několikaměsíčním předstihem. ${ }^{28}$

Bidlo brzy získal také zkušenosti s organizací Extenze z „vnitřku“ - pro akademický rok 1911/12 byl zvolen akademickým senátem do výboru Extenze. V té době, a prakticky až do přijetí nových stanov v r. 1926, zasedalo za českou univerzitu v rámci výboru pražské extenze deset, po osamostatnění přírodovědecké fakulty pak dvanáct osob. Po jednom zástupci volily profesorské sbory jednotlivých fakult s výjimkou fakulty filosofické, kdy ze dvou osob zpravidla jedna reprezentovala humanitní a druhá přírodní vědy. Čtyři zástupce (v praxi rovněž po jednotlivých fakultách) pak do výboru dodával akademický senát univerzity, který volil také předsedu. Celý výbor pak doplnilo ještě pět, později šest zástupců Českého vysokého učení technického, z jejichž řad vzešel místopředseda. Volba se opakovala každý rok, některé osoby ale zůstávaly ve funkci řadu let. To byl i př́pad Bidla, voleného akademickým senátem opakovaně členem výboru ${ }^{29}$ až do léta 1921, kdy byl zvolen předsedou a zůstal jím deset let.

Rozhodující pro setrvání ve funkci, zvláště v prrípadě předsedy, tak byla do roku 1926 nepochybně hlavně vůle dotyčného ujmout se úřadu znova. Jak František Č́a, který byl předsedou Extenze v době Bidlova vstupu do výboru, tak jeho následovník Filip Počta skončili ve chvíli, kdy na další nominaci nereflektovali; v př́ípadě F. Č́dy je dochován i př́slušný dopis. ${ }^{30}$

Opakované setrvání ve funkcích pak nepochybně podpořila realita světové války. Patrně s ohledem na rychlou eskalaci mezinárodněpolitické situace po atentátu na Ferdinanda

nevzdávám naděje (samit’ se nabídli), ale v každém případě přednášky - rozpočtené na 6 neděl - posouvají se tím na druhou polovici prázdnin, ačli je pořadatelstvo samo nepoloží na dobu ještě pozdější. Škoda, že se tím cestovní plány pp. přednášejících hatí. Jakmile dostanu jakoukoliv zprávu (jsem stále s kanceláří ve spojení), oznámím Vám okamžitě.“ Nakonec se Bidlovy přednášky měly konat ve dnech 10., 13., 17. a 20. září 1918, přičemž první dvě měly být věnovány slovanským dějinám obecně a další dvě dějinám Ruska. Ve skutečnosti se termín nejspíše ještě trochu posunul. MÚA, fond J. Bidlo, kart. 5, i. č. 377, V. Kybal J. Bidlovi, 1. 7. 1918, Smíchov (odtud první citát), 27. 7. (odtud druhý citát), 11. 8. a 10. 9. 1918, Černochov, p. Peruc. Ve Zlíně snad v dalších letech Bidlo přednášel znovu, soudě podle obsahu dvou nedatovaných dopisů předsedy Extenze F. Počty s organizačními pokyny (týkajícími se v jednom případě výslovně Zlína) a údaji o honoráři ve výši z doby po r. 1918 (100 K). MÚA, fond J. Bidlo, kart. 6, i. č. 500, F. Počta J. Bidlovi, s. d., s. 1.

28 MÚA, fond J. Bidlo, kart. 9, i. č. 840. Okresní osvětový sbor v Hořicích J. Bidlovi, 17. 2. a 18. 5. 1921 + cyklostylovaný letáček.

29 Z některých let se dochovaly i dopisy, jimiž volbu přijímá. AUK, Akademický senát UK, kart. 222, i. č. 3352, složka Lidové přednášky 1910-1911, J. Bidlo rektorátu České Karlo-Ferdinandovy univerzity, 12. 7. 1911, Praha; tamtéž, složka Lidové přednášky 1911-1912, J. Bidlo rektorátu České Karlo-Ferdinandovy univerzity, 12. 7. 1912, Praha; tamtéž, složka Lidové přednášky 1912-1913, J. Bidlo rektorátu České Karlo-Ferdinandovy univerzity, 10. 7. 1913, Praha.

30 AUK, AS UK, kart. 222, i. č. 3352, složka Lidové přednášky 1911-1912, F. Čáda Akademickému senátu K-FU, 4. 6. 1912, Praha. 
d'Este rozhodl akademický senát české univerzity, aby ve výboru Extenze setrvali její stávající zástupci. ${ }^{31}$ Tematika nabízených kurzů byla přizpůsobena aktuální situaci - tak již v zimním semestru 1914/1915 přednášel prof. E. Maixner O válečných epidemiích a ochraně proti nim, v letním semestru pak jeho kolega z lékařské fakulty V. Janovský na téma Nemoci nakažlivé a nauka o sdělování, včetně očkování, a vedle toho profesor české techniky J. Koloušek $O$ výživě a drahotě zvláštěv době válečné. I v následujících semestrech byly vypsány přednášky o problematice chovu domácích zvířat a zemědělství, o metalurgii ve službách válečného průmyslu, o národech a geografii Balkánu a Blízkého Východu (včetně kursu turečtiny), o potravinových náhražkách, o péči o válečné invalidy, nebo o hygieně a eugenice a byly pořádány ve zjevných souvislostech s dobovou situací. Přednáška prof. V. Janovského o pohlavních chorobách, na kterou byli počátkem března 1916 ,komandováni vojíni, takže se dostavilo několik setnin, jež samy by postačily na pětinásobné publikum", způsobila doslova srocení lidu a většina posluchačů se do sálu ani nedostala. ${ }^{32}$

Ani tyto okolnosti, ani upsání části financí Extenze na válečné půjčky neuchránilo instituci od vyšetřrování ze strany staroměstského policejního komisařství na počátku roku 1917. Výbor vypracoval obsáhlou zprávu, po níž ovšem následovalo zjišt’ování, jaké částky upsali na válečné půjčky jednotliví funkcionáři výboru pro pořádání lidových přednášek. Sestavením protestního vyjádření směřovaného $\mathrm{k}$ ministerstvu kultu a vyučování byl pověřen Bidlo, v té době působící zároveň ve funkci proděkana filozofické fakulty. Základem jeho argumentace bylo poukázání na to, že policejní komisařství výbor mylně ,,pokládá za spolek, ač výbor jest vlastně podnikem c. $k$. ministerstva a pokud se týče organisace, jest to komise, jejíž členové jsou jmenováni c. k. akademickými úr̆ady“. O válečných půjčkách jednotlivých členů profesorských sborů vysokých škol, jimiž byli také funkcionáři výboru pro pořádání lidových přednášek, navíc rektoráty pravidelně informovaly přímo ministerstvo kultu a vyučování. Vyšetřování tak podle Bidlovy argumentace postrádalo správné formální i věcné odůvodnění. ${ }^{33}$ Senát zároveň doporučil rovněž Bidlem formulovanou žádost ministerstvu o poskytnutí subvence ve výši $3000 \mathrm{~K}$ na pořádání ,zvláštních kursủ eugenických“ s odkazem na úspěch podobných předcházejících kurzů na jaře 1916 a podobně i žádost ministerstvu obchodu o částku $1000 \mathrm{~K}$ na pořádání kurzů „o hospodářských podmínkách zemí blizkého východu“. 34

Tak jako mnohé další instituce, reagoval i Výbor pro lidové přednášky českých vysokých škol pražských nedlouho po převratu na změny ve státoprávním uspořádání. Ještě v prosinci 1918 se obrátil nejprve na kulturní výbor Národního shromáždění a nedlouho poté na Ministerstvo školství a národní osvěty. V podání směřovaném $\mathrm{k}$ ministerstvu byly připomenuty dosavadní zásluhy vysokoškolských extenzí, členství v Mezinárodní federaci univerzitních extenzí a lidových univerzit a účast na jí pořádaných předválečných kongresech v Bruselu

31 AUK, AS UK, kart. 222, i. č. 3352, složka Lidové přednášky 1913-1914, děkan FF Jaroslav Vlček rektorátu, 23. 6. 1914, Praha; rektorát zvoleným zástupcům univerzity, 10. 7. 1914, Praha.

32 AUK, AS UK, kart. 222, i. č. 3352, složka Lidové přednášky 1916-1917, elaborát Z činnosti výboru pro lidové přednášky c. k. českých vysokých škol pražských v době válečné od podzimu 1914 do podzimu 1916.

33 AUK, AS UK, kart. 222, i. č. 3352, složka Lidové přednášky 1916-1917, J. Bidlo Akademickému senátu České Karlo-Ferdinandovy univerzity, 13. 7. 1917, Praha (autograf); Akademický senát Ministerstvu kultu a vyučování, 29. 7. 1917, Praha.

34 AUK, AS UK, kart. 222, i. č. 3352, složka Lidové přednášky 1916-1917, J. Bidlo Akademickému senátu České Karlo-Ferdinandovy univerzity, 13. 7. 1917, Praha (dva autografy); Akademický senát Ministerstvu kultu a vyučování a Ministerstvu obchodu, 29. 7. 1917, Praha (dvě samostatná podání). 
(1910) a Boloni (1912). Výbor požadoval poradní hlas při „každé oficiální, zejména legislativní akci směrujíci k reorganizaci české lidovýchovy [...] touže aspon̆ měrou, jakou jej mají jiné lidovýchovné ústřední organizace české". Výbor reflektoval také změny v oblasti vysokého školství a předjímal vytvoření extenzí vysokých škol na Moravě a na Slovensku, s nimiž by česká extenze mohla být spojena ,v jeden trojdílný institut extensní, který by mohl promyšleně a vzájemnou pomocí [...] působiti ve prospěch celého našeho národa a zejména jeho nerozborné jednoty duchovni a který by také imponoval cizině, hlavně slovanské, se kterou míni udržovati vrouci styky mezistátni"، S tím byly pochopitelně spojeny i požadavky na navýšení státní subvence, která byla v průběhu války snížena o dvě třetiny. ${ }^{35}$ Byl to dost pravděpodobně také zmíněný důraz na „slovanskou cizinu“, jenž posiloval Bidlovu pozici ve výboru.

V akademickém roce 1920/1921 byl Jaroslav Bidlo jedním z pěti členů výboru, volených akademickým senátem UK. Vedle něj byli dalšími členy profesoři František Vavřínek za právnickou fakultu, Karel Weigner za lékařskou fakultu a Alois Soldát za teologickou fakultu. Všichni v té době již měli za sebou mnohaleté organizační působení v Extenzi. Předseda výboru, paleontolog Filip Počta, byl původně ze stejné fakulty jako Bidlo, v té době už ale probíhala jednání o vydělení prírodovědných oborů z filozofické fakulty a ustavení samostatné př́rodovědecké fakulty. Ve výboru Extenze za UK dále zasedli členové volení př́mo jednotlivými fakultami: asyriolog a teolog Václav Hazuka, právní historik Miloslav Stieber, neuropatolog Ladislav Haškovec, botanik Karel Domin a sociolog Břetislav Foustka.

Když dosavadní předseda F. Počta na další působení ve výboru nereflektoval, byl na jeho místo zvolen František Slavík; ostatní členové výboru ve svém působení pokračovali. Předsedou zvolil akademický senát na svém zasedání 12. července 1921 jednomyslně Bidla. ${ }^{36}$ Odstupujícímu předsedovi F. Počtovi poděkoval rektor František Mareš ,za vše, co ...jako předseda tohoto výboru vykonal pro to, aby vědecké poznatky byly rozšireneny do nejširšich vrstev našeho národa. Činnost pro popularisování věd, kterou výbor pro pořádání lidových přednášek rozvinul, ziskala naši universitě i českému vysokému učeni technickému v Praze di̊stojné místo mezi cizími vysokými školami. Ona neušla také pozornosti činitelì zahraničních." 37

Volba akademickým senátem UK do funkce předsedy Výboru lidových přednášek českých vysokých škol pražských byla Bidlovi oficiálně oznámena již 12. července 1921;38 sám odeslal oficiální písemné potvrzení jejího přijetí až 21. záŕí 1921.39

Za příchodem Milady Paulové na post tajemnice pražské Extenze musíme nepochybně vidět právě osobu Jaroslava Bidla, v té době již jako předsedy. Nahradila slavistu Miloše Weingarta, který byl sekretářem pražské extenze od 29. listopadu 1919 do 3. ř́ijna $1921 .{ }^{40}$

35 AUK, AS UK, kart. 230, i. č. 3384, složka Lidové přednášky 1918-1919, předseda Výboru pro lidové přednášky českých vysokých škol pražských Filip Počta Ministerstvu vyučování (!) a národní osvěty, 9. 12. 1918, Praha (jedná se o dvě samostatná podání z téhož dne, jedno se týká finančních a druhé organizačních záležitostí Extenze).

36 Záznam o volbě a koncepty př́islušných oznámení v AUK, Akademický senát UK, kart. 230, i. č. 3384, složka Lidové přednášky 1920-1921.

37 Tamtéž, rektor F. Mareš F. Počtovi, 13. 7. 1921, Praha.

38 Tamtéž, rektorát UK J. Bidlovi, 12. 7. 1921, Praha (koncept).

39 Tamtéž, J. Bidlo rektorátu UK, 21. 9. 1921, Praha.

40 R. Horna - J. Opravil - M. Paulová, Extense, s. 26. Pro Weingarta místo sekretáře Extenze patrně znamenalo překlenutí provizoria před povoláním na vznikající bratislavskou filozofickou fakultu. Když byl Bidlo zvolen předsedou, dozvěděl se to Weingart zprvu neoficiálně od zřízence Kaprálka a písemně nad tím vyjadřoval „své 
Paulová tak byla nejen první československou docentkou, ale již předtím také první ženou, která intenzivně spolupracovala s jinak ještě dlouho plně mužským osazenstvem pražské extenze. I po skončení Bidlova předsednictví zůstávala nadále tajemnicí výboru. Rezignovala až poté, kdy se stala mimořádnou profesorkou, během zasedání výboru 23. října 1935. Nahradil ji opět docent z FF UK, Jan Blahoslav Čapek. ${ }^{41}$

Vedení sekretariátu Extenze pro ni představovalo patrně poměrně vítaný přivýdělek k platu v Univerzitní knihovně. ${ }^{42}$ Pro jejího předchůdce Vlastimila Kybala byl naopak plat za zastávání tohoto místa v letech 1906-1919 jediným trvalým př́ijmem, který průběžně doplňoval z jiných zdrojů. ${ }^{43}$ Se zajišt'ováním praktických každodenních záležitostí pro chod Extenze pomáhal Miladě Paulové zaměstnanec FF UK František Kaprálek. V jeho dochovaném spisu se k roku 1929 uvádí, že kromě řady dalších prací, včetně starosti o rozvrh hodin pro velkou posluchárnu, také „pořizuje v universitni extensi i prehehledy statistické, vyjednává venkovské přednášky telegraficky nebo telefonicky“. ${ }^{44}$ Když Paulová na přelomu let 1925/1926 na delší dobu onemocněla nebo když v r. 1927 získala stipendium na studijní cestu do Paříže, mohl ji tak do velké míry zastoupit. ${ }^{45}$

\section{Pražský výbor Extenze za Bidlova předsednictví do přijetí nových stanov (1921-1926)}

Již jako předseda pražské extenze se Bidlo účastnil I. říšského sjezdu československých učitelů vysokých škol, který se konal v Praze v budově ČVUT na Karlově náměstí 14. a 15. května 1922.46 Sjezd byl svolán z iniciativy Československého ústředního spolku

upřímné potěšení z různých důvodů, a také proto, že vedení Výboru přechází opět po delší době do oboru duchovědného“. Ve stručnosti shrnul aktuální stav příprav na podzimní přednášky a o svých dalších plánech uváděl: „Co se mne týče, nevím dosud vůbec, jaký bude můj další osud a zdali bratislavská fakulta bude vůbec $\mathrm{v}$ dohledné době zřízena; jisto je prozatím jen to, že středoškolské oddělení min[isterstva] šk[olství] a n[árodní] osv[ěty] rozhodlo, abych od 1. záři opět učil na reál[ném] gymn[asiu] smíchovském; budu tedy i nadále v Praze a mohu sekretářství zastávati.“ (To se ale mělo brzy změnit.) MÚA, fond J. Bidlo, kart. 8, i. č. 715, M. Weingart J. Bidlovi, 9. 8. 1921, Praha.

41 AUK, AS UK, kart. 230, i. č. 3384, zápisy ze schůzí výboru Extenze československých vysokých škol v Praze, 17. 6. 1936.

42 Ve stanovách z r. 1926 bylo výslovně uvedeno, že se jedná o funkci honorovanou „přiměřenou“ odměnou. V praxi se tak příslušné částky vyplácené Miladě Paulové a „zrrízenci“ Extenze Kaprálkovi v jednotlivých letech lišily a musely být vždy ad hoc schváleny výborem pražské extenze. Odměna v jednotlivých letech tak činila např. 500 Kč (8. 10. 1923). Když Paulová pobývala v r. 1927 na studijním pobytu v Paříži, Bidlo zařídil, aby jí byl na půl roku dopředu vyplacen plat. Archiv Kanceláře prezidenta republiky, sign. T. 1410/21, Milada Paulová, část I., kart. 61, M. Paulová P. Śámalovi před 26. červencem [1927].

43 J. HrdLIČKA, Historik a diplomat Vlastimil Kybal, s. 125.

44 AUK, fond Filosofická fakulta UK, kart. 84, i. č. 982, osobní spis F. Kaprálka, děkan FF UK rektorátu, 16.1. 1929, Praha. K jeho podílu na zajišt'ování chodu pražské extenze srov. také četné pasáže v korespondenci mezi předsedou a tajemnicí. Srov. D. Brádlerová - J. HÁlek (edd.), Jaroslav Bidlo - Milada Paulová. Střet generaci?, passim (dle rejstř́íku).

45 Byla mu za to přiznána mimořádná odměna $400 \mathrm{Kč}$, resp. v druhém př́ípadě $300 \mathrm{Kč}$. AUK, AS UK, k. 230, i. č. 3384. Zápisy ze schůzí výboru Extenze československých vysokých škol v Praze, nedatováno [počátek roku 1926] a 21. 11. 1927. Patrně i v této souvislosti mu na konci roku 1926 výbor schválil další dodatečnou odměnu ve výši 150 Kč za „mimořádné pisařské práce“. Tamtéž, 16. 12. 1926. V lednu 1932 je pak uváděna „obvyklá novoroční odměna 150 Kč za pomoc při účetní zprávě. Tamtéž, 20. 1. 1932.

46 Jeho jednání podrobně shrnuje publikace A. BEER - F. KADEŘÁvEK (edd.), Věstník I. ř́šského sjezdu československých učiteli̊ vysokých škol, Praha 1922. Není-li uvedeno jinak, údaje o organizaci a průběhu sjezdu jsou čerpány z této publikace. 
učitelů vysokoškolských (původně Českého) působícího od roku $1909 .{ }^{47}$ Jednalo se o hojně navštívenou, skutečně reprezentativní akci, na níž nechyběli delegáti zahraničních univerzit, zástupci ruské a ukrajinské emigrace a protektor sjezdu prezident T. G. Masaryk, který po zahájení osobně vystoupil s projevem, zdaleka ne jen formálním. Předsedou organizačního výboru byl profesor Lékařské fakulty UK Otakar Srdínko, s nímž se Bidlo osobně poměrně dobře znal. ${ }^{48}$ Jednání sjezdu bylo rozděleno do pěti sekcí: 1) pro všeobecné otázky; 2) pro mezinárodní vědecké a vysokoškolské otázky; 3 ) pro otázky organizace vysokých škol; 4) pro otázky studentské; 5) pro otázky stavovské. Sám Bidlo předsedal druhé ze sekcí, jejímiž místopředsedy byli chemik Emil Votoček a archeolog Albín Stocký. ${ }^{49} \mathrm{O}$ převzetí úvodního referátu $\mathrm{v}$ této sekci byl požádán přímo pořadateli. ${ }^{50}$ Bidlo byl jedním ze dvou profesorů historie z pražské filozofické fakulty, kteří na sjezdu vystoupili s př́ispěvkem (druhým byl G. Friedrich s referátem o potřebě nové československé encyklopedie). Václav Novotný, Josef Pekař a Josef Šusta sice jsou na seznamu účastníků uvedeni, je ale otázka, zda se jednání doopravdy účastnili a každopádně na rozdíl od Bidla a Friedricha aktivně nevystupovali v diskusích.

Ústřední téma sjezdu, jemuž byl dán prostor hned na počátku 1. sekce a jež bylo považováno za nejpalčivější z dalších projednávaných aktuálních problémů, préedstavovala otázka: „Jak přibližiti vysoké školy našemu lidu?" "51 S takřka totožně nazvaným příspěvkem ${ }^{52}$ vystoupil profesor české brněnské techniky, fyzik Vladimír Novák, který se na činnosti extenzí aktivně podílel již od jejich počátkủ. Nastínil v něm dosavadní vývoj extenzí (kromě pražského výboru existoval od r. 1904 ještě brněnský při tamní české technice), ale především se zamýšlel nad současnou situací. Srovnával české poměry s anglosaskými a americkými, kde byli posluchači vedle pasivní účasti na přednáškách mnohem více vtaženi do interakce s přednášejícím, mohli se zapojit do praktických kurzů a cvičení a ve výsledku tak získat i v praxi využitelné poznatky, což bylo důležité zvláště v př́padě kurzů pro učitele nižších stupňů. Novák připomněl zánik některých hodnotných aktivit extenzí, jako bylo publikování popularizačních přednášek, a poukázal na určitou ustrnulost forem působení extenzí, jež bylo podle jeho názoru třeba přizpůsobit a provázat s širokou paletou nově vzniklých kulturních a vzdělávacích institucí (středoškolské kurzy, osvětové svazy, dělnické akademie apod.), jejichž rozvoj přičítal částečně i nedostatečné aktivitě extenzí.

47 K jeho dějinám přehledně Gustav FrIEDRICH, Listy z činnosti Českého ústředního spolku učitelů vysokoškolských, in: A. Beer - F. Kadřávek (edd.), Věstník, s. 3-8. Friedrichův text končil pasáží o dřívějším a aktuálním vztahu spolku a Extenze: „Jinou takovou otázkou [vedle zř́żení univerzity v Brně], o kterou se spolek také již pokusil, bylo organizování popularizační činnosti vysokoškolského učitelstva. Protože však tato činnost byla soustředěna v rukou výboru pro pořádání lidových přednášek, pustil spolek časem tuto činnost ze zřetele a teprve v poslední době se k ní zase vrátil, dav zatím podnět k tomu, aby se vysokoškolské extenze přetvořily v lidovou vysokou školu, která by překlenula propast mezi soběstačnou činností ryze vědeckou a mezi vlastním životem národa, a pomáhajíc povznášeti vzdělání širokých vrstev všeho občanstva, oddala se uskutečňování humanitních ideálů největšího kdysi našeho soudruha v povolání a tak přibližovala vysoké školy lidu.“ Tamtéž, s. 8.

48 Srov. korespondenci v MÚA A AV ČR, fond J. Bidlo, i. č. 591.

49 Srov. také MÚA, fond J. Bidlo, kart. 9, i. č. 851. Výbor I. říšského sjezdu československých učitelů vysokých škol J. Bidlovi, 1. 3. 1922, Praha (oznámení o volbě předsedou komise).

50 MÚA, fond J. Bidlo, kart. 3, i. č. 61, A. Beer J. Bidlovi, 31. 1. 1922, Praha.

51 O. S. [=Otakar SRDínko], První řišský sjezd československých učitelů vysokých škol. Slovo úvodní, in: A. Beer F. Kadeřávek (edd.), Věstník, s. 1-3, zde s. 2.

52 V. NovÁk, Jak přibližiti vysoké školy lidu?, s. 79-85; diskuse k příspěvku na s. 85-94. 
Velkou část diskuse $\mathrm{k}$ př́íspěvku V. Nováka zabral návrh sociologa a člena pražské extenze Břetislava Foustky na přetvoření extenzí v „Lidovou univerzitu“. Jednalo se o námět, který byl již dříve konzultován s brněnskou a bratislavskou extenzí. Debatu, v níž se začaly ozývat některé vášně odpůrců lidovýchovných konceptů, uklidnil předseda bratislavské extenze Miloš Weingart konstatováním směřujícím k nejvíce neuralgickým bodům (pragocentrismus, radikalismus, otázka zkoušek a potvrzení): „Mohu dosvědčiti, že stanovy lidové university nebyly projednávány jenom v Praze, nýbrž že byl návrh poslán i do Bratislavy a na jeho základě že se u nás připravují stanovy místní odbočky lidové university. Dále mohu prohlásiti, že není to nic jiného než extense, v hrubých rysech plán extense jest zachován, jenom program jest rozšíren a složení výboru pozměněno. Dále dosvědčuji, že zkoušky v tomto návrhu stanov nejsou prohlášeny za neodlučitelnou a nezbytnou součást, nýbrž že se v jednom paragrafu stanov praví, že se má sestaviti zvláštní zkušební ř́d“.53

Jednání sekce i debata skončily přijetím rezoluce, jež sestávala z pěti bodů, týkajících se i budoucnosti extenzí: 1) Ústřední výbor ČÚSUV měl zvolit komisi, která by se zástupci jednotlivých tř́i výborů jednala o reformě extenzí. 2) V této souvislosti měla proběhnout anketa za účasti všech významných lidovýchovných korporací. 3) Na vládu měl směřovat apel respektující výsledky uvedené ankety a zdůrazňující nedostatečné prostředky vysokoškolských extenzí. 4) O uvedených jednáních měla být informována zainteresovaná veřejnost, u níž se také měla hledat odpovídající podpora. 5) O těchto aktivitách mělo být referováno rovněž ,panu presidentu Masarykovi jako zakladateli vysokoškolských extensí $u$ nás" a měly být zohledněny jeho případné rady a pokyny. ${ }^{54}$

Samotné extenze (brněnská a bratislavská tedy již záhy po svém vzniku) opravdu procházely snahami o reorganizaci, jejichž nejdůležitější součástí byla diskuse o nových stanovách. Průvodní dopis pražského výboru akademickému senátu zdůvodňoval úpravy stanov důvody, jež se víceméně shodovaly s postuláty sjezdu vysokoškolských učitelů: „Východištěm snahy, aby dosavadni stanovy byly změněny a opraveny, byl jednak státní prevrat, který se stal v naši vlasti při skončení světové války, jednak poznání, že lidovýchova prováděná v ústavě, který jest součástkou a výborem vysokých škol, musi býti postavena na nové základy, má-li snésti soutěž lidovýchovy, prováděné jinými ústavy, které v prüběhu 23-letého trvání universitní extense vznikly vedle ní a odňaly jí velikou část jejího žactva. "55 Návrh vyzdvihoval provázanost odborných a popularizačních kompetencí vysokoškolských pedagogů (ty byly ostatně opravdu u řady osobností nezpochybnitelné) s praktickou výukou exaktních věd vyžadující odpovídající přístroje a laboratoře a s nestranností, již nemohly zaručit lidovýchovné instituce organizované na stranické nebo sociální bázi.

Je jistým paradoxem, že zpočátku sami představitelé extenze neshledávali tento neoficiální termín jako vhodný k běžnému užívání: „Dosavadní sáhodlouhý a těžkopádný název byl všeobecně uznán za zastaralý a nevhodný. Název universitni extense byl shledán nečeským a nevyjadrujicím náležitě ideu a cíle vysokoškolské lidovýchovy. Naproti tomu název «Lidová universita» byl uznán za poměrně nejvhodnějši svou krátkostí a jasností. Vètšina

53 A. BEer - F. KaDEŘÁVEK (edd.), Věstník, s. 92.

54 A. BEER - F. KADEŘÁVEK (edd.), Věstník, s. 93.

55 AUK, AS UK, kart. 230, i. č. 3384, složka Lidové přednášky 1921-1922, předseda Výboru pro pořádání lidových přednášek českých vysokých škol pražských (J. Bidlo) Akademickému senátu UK, 16. 6. 1922, Praha + př́loha (návrh stanov „Lidové university československé“). Z tohoto obsáhlého elaborátu pocházejí i údaje a citáty v následujících odstavcích, dokud není uvedeno jinak. 
členů Výboru sice vyslovila proti němu některé námitky, jmenovitě také právní povahy, ale posléze zavládlo všeobecné presvědčení, že jiného vhodnějšiho názvu nelze najíti. Původně měl se budoucí ústav nazývati «Lidová universita pražská», avšak řřšský sjezd vysokoškolských učitelù přinesl poznání, že vysokoškolská pražská lidovýchova musí zůstávati $v$ nejtěsnějšim styku s lidovýchovou brněnskou a bratislavskou a tvoriti s nimi dohromady jeden celek, ovládaný týmž vědeckým a národním duchem a ř́zený stejným směrem. Proto bylo usneseno, aby byly tyto snahy vyjádřeny v nových stanovách společným již názvem všech tu vysokoškolských lidovýchovných těles, které však maji zůstávati úplně samostatnými celky. Poněvadž se v posledni době vyskytlo několik lidovýchovných ústavì, které si usurpuji název «Lidová universita», soudí Výbor, že by akademický senát měl učiniti kroky, aby tento název byl vyhražen pouze novému lidovýchovnému tělesu československých vysokých škol.“ Tím se vysvětluje, proč se představitelé extenzí nakonec museli pokorně vrátit k cizojazyčnému označení, když se ukázalo, že podřízení se nově vznikající a potenciálně zastřešující lidovýchovné instituci by nejspíše znamenalo úplnou ztrátu svébytnosti univerzitních extenzí (srov. níže pasáže týkající se Masarykovy lidové univerzity).

Snad ještě větší kontroverze budila otázka udělování vysvědčení a nejrůznějších potvrzení o absolutoriu ze strany lidovýchovných institucí a jejich potenciálního zneužívání, např. pro získání místa ve státní službě. Výbor dále v návrhu bagatelizoval svou odpovědnost akademickým senátům vysokých škol s poukazem na někdejší nepřízeň vídeňské vlády a žehral na omezenou výši státních subvencí (30 000 Kč) ve srovnání s podporou politických stran: „Kdyby mistní lidová universita pražská obdržela od vlády roční subvenci jen 200.000 Kč, tedy méně než polovici toho, co vláda dala jednotlivým politickým stranám [na lidovýchovnou činnost], zř́dila by takovou školu lidovou, že by ostatní lidovýchovné ústavy za ní daleko pokulhávaly. "56

Bidlo jakožto předseda pražského výboru musel jistě myslet i na budoucí práci svou a Milady Paulové v rámci reorganizované extenze, když v odůvodnění nových stanov líčil funkci sekretáře jako práci na plný úvazek, vyžadující zároveň součinnost zrŕizence pro vykonávání pomocných prací (zejména psaní). Hlavní slovo ale měl mít předseda: „Vzhledem k velikým úkolům, které očekávají «Lidovou univerzitu» není možno, aby vi̊dč́m činitelem jejím byl jen sekretář́, poněvadž náležité provedení organisace její vyžaduje ruky osvědčeného vědeckého badatele a lidového učitele v jedné osobě. Předseda "Lidové university» bude skutečně vlastně jejím ředitelem, který bude muset znáti a sledovati do podrobností její činnost. “ Časově náročná a zodpovědná činnost vyžaduje také náležité finanční ohodnocení, které ale ve vztahu k předsedovi a ostatním členům výboru nemělo mít povahu stálého př́ijmu, ale jednorázové a akademickým senátem schválené odměny až podle konkrétních výsledkủ. Dodejme předem, že navzdory poměrně dalekosáhlým plánům na reorganizaci, se meziválečná praxe extenze spíše blížila předválečným poměrům - včetně otázky finančního ohodnocení, členové výboru i nadále nebyli za svou činnost honorováni. Hlavním důvodem zbrzdění náběhů k podstatnější reorganizaci extenzí byl krach jednání, směřujících $\mathrm{k}$ takové variantě spolupráce lidovýchovných organizací, která

56 Na tomto místě Bidlo v elaborátu jen otevřeněji pojmenovával jev, který v korektnější formě zmiňoval již Vladimír Novák ve svém příspěvku na sjezdu vysokoškolských učitelů o měsíc dříve: „Vláda bude nucena přiděliti větší část z obnosu pro lidovou výchovu na vysokoškolské extense, než jaká byla určena letos nebo loni. Naprosto pak nelze připustiti, aby velká většina peněz ustanovených na lidovou výchovu byla (jako se to stalo minulého roku) přesunuta na účet zcela jiný.“ V. NovÁK, Jak přibližiti vysoké školy lidu?, s. 84. 
by byla přijatelná pro představitele vysokých škol (a to nejen činovníky extenzí, ale také členy akademických senátů).

Rozhodnutí o směřování cestou mírných změn, podpořené také debatou nad novými stanovami Extenze v Akademickém senátu UK 22. července 1922, se stalo poměrně brzy základem pro další vývoj. Ten měl být ovlivněn především snahami o lepší finanční zabezpečení než o strukturální organizační změny. ${ }^{57}$

V průběhu roku 1922 se rovněž řešila otázka zřízení Lidovýchovného ústavu, resp. Masarykovy lidové univerzity a jejího poměru k extenzím. V př́pravách tohoto projektu byla zaangažována mj. Dělnická akademie a především Československý svaz osvětový. Na celý projekt byla z Masarykova národního fondu věnována částka 4 milióny korun. Sám Bidlo byl toho názoru, že se od doby původního návrhu na zřízení zastřešující lidovýchovné instituce situace významně změnila, a to zejména ustavením extenzí v Brně a v Bratislavě. Tento stav věcí měl být zohledněn v nových stanovách Extenzí, jež už byly v té době projednávány $\mathrm{v}$ profesorských sborech fakult a v senátu. Velkou nevoli přitom vzbuzovala dle očekávání možnost konání zkoušek a název Lidová univerzita. Výbor se pod Bidlovým vedením snažil zajistit si v budoucí organizaci vědecké osvěty klíčovou a zároveň dostatečně autonomní pozici, a to i za cenu, že by nemohl využít nic ze zamýšlené velkorysé finanční dotace. ${ }^{58}$

Nic na tom v polovině roku 1924 prakticky nezměnil ani návrh, že by se Extenze staly jedním z pěti kmenových členů MLÚ. V dalším kole „námluv“ nakonec dospěl pražský výbor k závěru, že se Extenze nemohou stát členem MLÚ, ,ježto jejich charakter je zcela odlišný od ostatnich spolků. Extense jsou institucemi vysokých škol, podléhají v mnohém akademickým senátům, a proto nemohou býti vázány jako "kmenový» člen v jiné institu$c i$ “. S takto zdůvodněnou negativní odpovědí, s níž měla být seznámena také vláda a jíž se Extenze zříkaly potenciálního nároku na podíl ze čtyřmilionové částky z Masarykova národního fondu, měl být spojen pokus o navýšení dosavadní roční dotace zhruba o polovinu (ze 70 000, na něž mezitím subvence stoupla, až na 100000 Kč). ${ }^{59}$ Pražský výbor pak čekal na odpověd' z Brna, zatímco př́iznivci propojení s MLÚ (jazykovědec prof. František Pastrnek) se snažili dosáhnout přehodnocení dosavadních závěrů. ${ }^{60}$ Brněnská extenze, snad po jistém váhání, návrh pražského výboru podpořila. Zamýšlená odpověd' tak mohla být odeslána Osvětovému svazu a na vědomí vládě. ${ }^{61}$

57 V př́ípisu, jímž byli na počátku roku 1923 osloveni děkani fakult UK s žádostí o podporu návrhu, který měl směřovat k Ministerstvu školství a národní osvěty, se uvádělo: „Za jednání [Akademického senátu UK] bylo z mnohých stran poukazováno na to, že prŕíčina, pro kterou Výbor nemohl dosud rozvinouti plnou a všeobecně uspokojující činnost, vězí spíše v nedostatku peněz, který nepřipouštěl, aby byl vypracován náležitý program pro činnost Výboru a program ten byl dodržován, nežli v nedostatku dosavadní organisace.“ AUK, AS UK, kart. 230, i. č. 3384, složka Lidové přednášky 1923-1924, předseda Výboru pro pořádání lidovýchovných přednášek vysokých škol pražských proděkanovi FF UK V. Tillemu, 7. 2. 1923, Praha.

58 „Na to se ukládá referentům ve sborech profesorských, aby projednání otázky podle možnosti a poměrů urychlili a vzhledem k přístímu jednání o MLÚ přijímá se návrh prof. Haškovce: aby předseda, až k němu dojde, prohlásil, že Výboru, jako lidových[ovné] instituci čes[kých] vy[okých] škol, bud' bude v MLÚ vyhraženo místo první a vedoucí, které mu přísluší, anebo že Výbor zůstane samostatný a bude působiti paralelně a že dává vládě na vůli, aby zmíněné 4,000 000 Kč rozdělila podle svého uznání.“AUK, AS UK, kart. 230, i. č. 3384, zápisy ze schůzí výboru Extenze československých vysokých škol v Praze, 20. 12. 1922.

59 Tamtéž, 24. 6. 1924.

60 Tamtéž, 6. 11. 1924.

61 Tamtéž, 12. 2. 1925. 
Když Osvětový svaz svou nabídku na konci roku 1925 opakoval s tím, že Extenze by ted' byly jednou ze 111 institucí sdružených v radě Masarykova lidovýchovného ústavu, vzbudil tento návrh u členů pražského výboru všeobecné pohoršení. Požadovali, aby se Extenze ohradily „ostře a di̊razně“. Právník profesor Vavř́nek tento požadavek konkrétně rozvedl, totiž aby „Výbor v odpovédi ukázal na podceňující způsob, když tak stará instituce, jako je Extense, má býti zařazena mezi 111 jiných korporací a vyslovil přesvědčení, že se v tomto celku nelze nadíti žádné zvláštní působnosti pro nás“. ${ }^{62}$

Žádné námitky naopak nebyly proti tomu, aby měly Extenze zastoupení v nově vznikajícím Okresním osvětovém sboru pro Prahu. Výbor touto funkcí na podzim 1924 pověřil předsedu, tedy J. Bidla. ${ }^{63}$ Když se ukázalo, že s členstvím by mohly být spojeny neočekávané a nežádoucí povinnosti, schválil výbor obratem příslušné usnesení, aby předseda nebyl zbytečně zatížen dalším náročným závazkem. ${ }^{64}$

Funkce předsedy pražské vysokoškolské extenze s sebou nesla řadu potenciálně nepř́íjemných a komplikovaných jednání. Tak byl Bidlo na konci roku 1922 pověřen, aby jednal s předsedou brněnské extenze prof. Vladimírem Novákem v otázce výše honorářů. V Brně totiž po získání finanční podpory ze strany Osvětového svazu o své vůli zvedli honoráře přednášejícím na $250 \mathrm{Kč}$, a teprve dodatečně se snažili získat pro svůj krok podporu u extenzí v Praze a Bratislavě. Kompromisní návrh, který měl Bidlo prezentovat, byl honorář přednášejícím ve výši 200 Kč od 1. ledna 1923. Hned v počátcích svého působení na postu předsedy pražské extenze musel také řešit nesoulad v rámci vlastní pražské extenze, kdy ČVUT začalo o své vůli vyhlašovat a konat lidovýchovné přednášky bez koordinace s UK v rámci výboru. Návrh na spojení těchto „všeobecných vzdělávacích technických prednášek"s Extenzí ale senát ČVUT neschválil, protože na ně škola získala samostatnou subvenci. 65

V souvislosti s podnětem z Banské Bystrice měla být zorganizována zvláštní série přednášek pro Slovensko, pro niž výbor zamýšlel získat mimořádnou subvenci z ministerstva. To se skutečně podařilo (jednalo se o částku ve výši 10000 Kč). Přednášky, které se konaly v Trenčíně, Žilině, Martině, Zvoleně a Banské Bystrici měly uspokojivý ohlas a zahrnovaly právní, slavistická a historická témata. ${ }^{66}$

62 Tamtéž, 7. 12. 1925.

63 Tamtéž, 6. 11. 1924.

64 „Předseda referuje o schůzi svolané Radou hlav[ního] města Prahy za účelem zřízení Osvět[ového] sboru hlav[ního] města Prahy. Jednání bylo skončeno zvolením pětičlenné komise, do které byl zvolen i předseda, aby ta vypracovala bližší program činnosti této instituce. V celém jednání se jevilo, že pořadatelé nejsou si vědomi cíle a zvláště metod, jak uskutečniti myšlenku v praxi, a zdá se, že břímě má býti svaleno na jednotlivé pozvané členy, zvláště vysokoškolské profesory, na které zejména bylo apelováno. K návrhu prof. Weignera vyzván předseda, aby z usnesení výboru v Komisi prohlásil, že se jí účastní jen ad informandum a že za Extensi nemůže přijímati žádných závazků.“AUK, AS UK, kart. 230, i. č. 3384, zápisy ze schůzí výboru Extenze československých vysokých škol v Praze, 12. 2. 1925.

65 AUK, AS UK, kart. 230, i. č. 3384, zápisy ze schůzí výboru Extenze československých vysokých škol v Praze, 20. 12. 1922 a 8. 10. 1923. Dále také tamtéž, složka Lidové přednášky 1922-1923, předseda Výboru pro pořádání lidových přednášek vysokých škol pražských (J. Bidlo) Akademickému senátu UK, 18. 1. 1923, Praha + př́loha (opis vyjádření představitelů brněnské extenze k otázce výše honorářů); D. BRÁDLEROVÁ - J. HÁLEK (edd.), Jaroslav Bidlo-Milada Paulová. Střet generací?, s. 270.

66 AUK, AS UK, kart. 230, i. č. 3384, zápisy ze schůzí výboru Extenze československých vysokých škol v Praze, 20. 12. 1922 a 8. 10. 1923. O přípravách také D. Brádlerová - J. HÁlek (edd.), Jaroslav Bidlo - Milada Paulová. Střet generací?, s. 270. 
Zanedlouho došlo k ustavení samostatné extenze v Bratislavě, jejíž zástupce Miloš Weingart se tak již mohl zúčastnit porady předsednictva všech tř́i extenzí konaného 22. prosince 1922. ${ }^{67}$ Její účastníci dospěli k domluvě o užší součinnosti a k dohodě o honorárích za přednášky ve smyslu výše uvedených návrhů pražské extenze. ${ }^{68}$ Je samozřejmě třeba mít na paměti, že ačkoli předseda brněnské extenze prof. Vladimír Novák měl silné vazby k brněnskému a vůbec moravskému prostředí již před I. světovou válkou, většina zástupců mimopražských extenzí včetně něj byla svým předchozím působením vázána převážně k Univerzitě Karlově. Časem ale dominantní postavení pražské extenze přece jen poněkud oslabovalo.

Př́znivě byl přijat návrh profesora Václava Tilleho, aby byl podle vzoru Mezinárodní akademie pro studium sociální a politické uspořádán kurs o mírovém hnutí, u něhož se očekával značný zájem veřejnosti (byt' původní Tilleho představy byly poněkud zredukovány). ${ }^{69} \mathrm{~V}$ této otázce se angažovala i Ženská liga pro mír a svobodu. ${ }^{70}$

Opakovaně byl na pořadu jednání podíl Extenze na vzdělávání učitelů nižších škol. Odmítnuty byly snahy o snížení honorářù vysokoškolských profesorů podílejících se na kursech zprostředkovávaných Československou obcí učitelskou pro Vysokou školu pedagogických studií a učitele měšt’anských škol. Bidlo jako předseda Extenze svolal 27. září 1923 „schi̊zi všech profesorů, kteři mají přednášeti letošního roku na Škole vysokých studii pedagogických“. S odkazem na domluvu se zástupci ostatních dvou extenzí navrhoval, „že vysokoškol[ští] učitelé, pokud přednášeji v kursech mimo vysoké školy, mají se ustaviti ve zvláštni učit[elský] sbor a ten vystupovati jednotně a hájiti jejich zájmư“. Ačkoli Bidlo navrhoval několik alternativ, které by Vysoké škole pedagogických studií vyšly částečně vstříc, také jemu bylo zjevně nejbližší stavovské hledisko, které v debatě v pražském výboru převážilo. A to, že „,honorář je stanoven již tak velmi nízo, kdežto se na druhé straně klade na vysokošk [olské] učitele požadavek, aby věnovali učit[elským] kursům své poslední volné sobotní a nedělní hodiny“. Zdůrazňovalo se přitom, že „učitelé, jako pracovníci intelektuální, sami by měli v zájmu oceňování duševní práce trvati na slušných honorárích a usilovati spíše o to, aby ministerstvo zvýšilo subvence“.

Bidlo byl následně zvolen do komise, která měla vypracovat pro ministerstvo zdůvodnění požadavku vysokoškolských pedagogů na vyšší honoráře vzhledem k vyšším nárokům kladeným na jejich práci. ${ }^{71} \mathrm{~V}$ praxi nakonec výbor pražské extenze souhlasil s částečným dotováním honorářů přednášek vysokoškolských pedagogů pro Vysokou školu pedagogických studií. ${ }^{72}$ Ukázalo se ale, že podle výkladu MŠANO stejně nelze dotaci Extenze na

67 Pražskou extenzi na schůzce reprezentovali J. Bidlo, V. Tille a V. Felber, brněnskou V. Novák a bratislavskou M. Weingart. O dohodě týkající se společného vystupování všech tř́ extenzí navenek byl informován Akademický senát UK a analogicky jistě i akademické senáty ostatních vysokých škol. Srov. AUK, AS UK, kart. 230, i. č. 3384, složka Lidové přednášky 1922-1923, předseda Výboru pro pořádání lidových přednášek vysokých škol pražských Akademickému senátu UK, 18. 1. 1923, Praha.

68 AUK, AS UK, kart. 230, i. č. 3384, zápisy ze schůzí výboru Extenze československých vysokých škol v Praze, 20. 3. 1923 .

69 AUK, AS UK, kart. 230, i. č. 3384, zápisy ze schůzí výboru Extenze československých vysokých škol v Praze, 20. 3. 1923.

70 D. Brádlerová - J. HÁleK (edd.), Jaroslav Bidlo - Milada Paulová. Střet generací?, s. 268n.

71 AUK, AS UK, kart. 230, i. č. 3384, zápisy ze schůzí výboru Extenze československých vysokých škol v Praze, 8. 10. 1923.

72 Jednalo se o částku 20 Kč na každých 100 Kč honoráře do celkové výše 12000 Kč. AUK, AS UK, kart. 230, i. č. 3384, zápisy ze schůzí výboru Extenze československých vysokých škol v Praze, 7. 12. 1925. 
tento účel použít. ${ }^{73}$ Přes nespokojenost přednášejících tak výbor při hlasování těsnou většinou rozhodl, že tento typ přednášek, jež měly spíše seminární charakter, má být honorován nižší částkou $(50 \mathrm{Kč}){ }^{74}$

Dodejme, že Bidlo sám byl Československou obcí učitelskou osloven, aby na Vyšší škole pedagogických studií v zimním semestru 1925/1926 přednášel pro kandidáty učitelství na měštanských školách. Přednášky na téma Přehled dějin světových, s jejichž uskutečněním souhlasil, se měly konat vždy v sobotu před polednem, měly trvat dvě vyučovací hodiny a jeho měsíční honorář měl činit 100 Kč..$^{75}$ Pro studijní rok 1924/1925 byl navržen jeho semestrální kurs ze všeobecných dějin. ${ }^{76}$ Celkově se ale Bidlo během svého předsednictví už do přednáškových aktivit Extenze zapojoval minimálně. Důvodem byla jistě i jeho značná pracovní vytíženost $\mathrm{v}$ řadě jiných institucí a poměrně intenzivní publikační činnost. ${ }^{77}$

Velmi vstřícná byla pražská extenze vůči menšinovému školství. Když na konci roku 1925 oslovil její výbor vídeňský český spolek Komenský s prosbou o bezplatné uspořádání řady přednášek, bylo jí obratem vyhověno a pro jednotlivé přednášející byl vyčleněn velkorysý honorář ve výši 1000 Kč za přednášku, resp. 1500 za dvě přednášky. Bidlo při té príležitosti neopomněl nadhodit možnost zkusit získat od ministerstva pro tento účel samostatnou subvenci. ${ }^{78}$ Přednášky nakonec Extenze zvládla k oboustranné spokojenosti ve své vlastní režii a plánovala na ně v r. 1926 navázat přednáškovým turné prof. J. V. Šimáka i po dalších velkých rakouských městech (Linec, Štýrský Hradec, Vídeň). ${ }^{79}$

V otázce vztahu Extenzí k dalším institucím, jako byl např. Československý svaz osvětový nebo Československá obec učitelská, se Bidlo snažil dosáhnout celorepublikového konsensu. Jednání s předsedou brněnské extenze fyzikem Vladimírem Novákem mu nejspíše usnadňovala stará známost $\mathrm{z}$ doby, kdy působil v Praze. Počátkem roku 1924 tak od něj na osobní schůzce získal slib, že v otázce pořádání učitelských kurzů pro Československou obec učitelskou, na něž brněnská extenze připlácela přednášejícím po 20 Kč za přednášku, bude $\mathrm{v}$ souladu s postupem pražské extenze požadovat plné převzetí nákladů organizátory. ${ }^{80}$ Po dalším jednání s Československou obcí učitelskou nakonec učinil výbor pražské extenze vstř́ícný krok a rozhodl se vyřešit spornou částku (př́ídavek 20 Kč za přednášku) získáním dodatečné subvence. Bidlo měl společně s profesorem Weignerem v této

73 Tamtéž, nedatováno [počátek roku 1926].

74 AUK, AS UK, kart. 230, i. č. 3384, zápisy ze schůzí výboru Extenze československých vysokých škol v Praze, 3. 2.1927.

75 MÚA, fond J. Bidlo, kart. 9, i. č. 775. Předseda a tajemník Československé obce učitelské J. Bidlovi, 10.10. 1925, Praha.

76 AUK, AS UK, kart. 230, i. č. 3384, zápisy ze schůzí výboru Extenze československých vysokých škol v Praze, 10. 3. 1924 a 6. 11. 1924.

77 K jeho vytíženosti v prvním poválečném desetiletí srov. Marek ĎurČAnsKÝ, Jaroslav Bidlo jako osoba veřejná, in: Dagmar Blümlová a kol., Čas optimismu a ctižádostivých nadějí. Prezentace a reprezentace české vědy a kultury v prvním desetiletí samostatného státu (1918-1929), České Budějovice 2009 (=Jihočeský sborník historický - Supplementum 1), s. 57-66.

78 AUK, AS UK, kart. 230, i. č. 3384, zápisy ze schůzí výboru Extenze československých vysokých škol v Praze, 7. 12.1925.

79 Tamtéž, nedatováno [počátek roku 1926]. Přednášky se konaly v červenci 1926. Srov. Hana KÁBovÁ, Josef Vitězslav Šimák. Jeho život a dílo se zvláštním zřetelem k historické vlastivědě, České Budějovice - Pelhřimov, 2013, s. 403; R. Horna - J. Opravil - M. Paulová, Extense, s. 53.

80 AUK, AS UK, kart. 230, i. č. 3384, zápisy ze schůzí výboru Extenze československých vysokých škol v Praze, 10. 3. 1924 . 
záležitosti navštívit př́mo sekčního šéfa MŠANO dr. Kolínského. ${ }^{81}$ Weigner se také o rok později ujal jednání s ministerstvem ohledně možnosti převádění nevyčerpaných subvencí Extenze do následujícího roku. ${ }^{82}$

Záležitosti financování Extenzí ostatně patřily mezi nejdůležitější agendu předsedy a tajemnice. Dosavadní systém subvencí se od roku 1925 rozšríril o jednorázový př́spěvek z ministerstva veřejného zdravotnictví ve výši 50000 Kč, přičemž si organizaci odborného programu vzal na starost prof. Weigner, který celou záležitost také inicioval. ${ }^{83}$

Jakýmsi vrcholem průběžné kontroly účtů bylo ustanovení komise akademického senátu, která na jaře 1925 za součinnosti dvou členů výboru zkontrolovala vedení ekonomických záležitostí pražské extenze. Jednalo se o důsledek dlouhodobějších nedorozumění s kvesturou, takže o revizi účetnictví poté, co Milada Paulová sama prošla starší podklady, požádalo samo vedení Extenze. ${ }^{84} \mathrm{Na}$ postu kontrolorů se z nominace senátu UK ocitli právník Josef Drachovský a prŕrodovědec František Slavík, Extenzi zastupovali profesoři Posejpal a Svoboda. Výsledkem činnosti komise bylo odstranění sporů mezi univerzitní kvesturou a Extenzí vzniklých v důsledku účetnictví za války (vykazování úroků) a táhnoucích se již od té doby. ${ }^{85}$

Jak již bylo naznačeno, zásadní organizační otázku představovala od počátku 20. let příprava nových stanov Extenzí. Výbor značně ustoupil připomínkám ze strany fakult, např̀ v otázce pojmenování orgánů Extenze (nikoli senát, ale výbor; nikoli presidium, ale předsednictvo). Přes protest zástupce teologické fakulty rozhodl výbor o jejím vyloučení $\mathrm{z}$ Extenze (ve výboru měla zvláště nemilosrdného nepř́tele $\mathrm{v}$ profesoru právnické fakulty Emilu Svobodovi) ${ }^{86}$ Až do doby, kdy v roce 1926 vstoupily v platnost nové stanovy, sice teologická fakulta nadále měla své dva zástupce ve výboru pražské extenze, byla ale výrazně upozaděna. Od roku 1926 nebyla ve výboru zastoupena vůbec.

\section{Pražská extenze za předsednictví J. Bidla po přijetí nových stanov Extenzí (1926-1931)}

Návrh nových stanov měla Ministerstvu školství a národní osvěty podle usnesení výboru z jara 1924 předložit komise, které Bidlo předsedal a vedle něj v ní zasedali profesoři Foustka, Velich a Mildschuh. ${ }^{87}$ Ještě počátkem roku 1926 ale musel Bidlo potvrzení stanov na ministerstvu urgovat tak, aby vešly v platnost do začátku nového školního roku a nové

81 Tamtéž, 6. 11. 1924.

82 Tamtéž, 7. 12. 1925.

83 Tamtéž, 12. 2. 1925.

84 AUK, AS UK, kart. 230, i. č. 3384, složka Lidové přednášky 1924-1925, předseda Výboru pro pořádání lidovýchovných přednášek vysokých škol pražských Akademickému senátu UK, 25. 2. 1925, Praha.

85 AUK, AS UK, kart. 230, i. č. 3384, zápisy ze schůzí výboru Extenze československých vysokých škol v Praze, 7. 12. 1925.

86 Tamtéž, 20. 3. 1923. Srov. také tamtéž, složka Lidové přednášky 1922-1923, předseda Výboru pro pořádání lidovýchovných přednášek vysokých škol pražských (J. Bidlo) Akademickému senátu UK, 24. 4. 1923, Praha (výbor tlumočící zároveň názor světských fakult UK i ČVUT trvá na formulaci „fakulty a vysoké školy theologické nemají zástupců v Extensích“v návrhu znění stanov).

87 AUK, AS UK, kart. 230, i. č. 3384, zápisy ze schůzí výboru Extenze československých vysokých škol v Praze, 10. 3. 1924 . 
volby do výboru už mohly být provedeny podle nich. ${ }^{88}$ To se skutečně podařilo: 26 . června 1926 rozhodlo MŠANO (s přihlédnutím k souvisejícím podáním brněnské a bratislavské extenze) o schválení nových stanov s několika spíše drobnými úpravami. ${ }^{89}$ Na podzim 1926 tak volby na UK a ČVUT skutečně proběhly.

Podle nových stanov zněl nyní oficiální název Extense československých vysokých škol $v$ Republice československé (Přednášky pro dospělé). ${ }^{90}$ Smyslem reorganizované instituce bylo zajišt'ovat „,šem vrstvám obyvatelstva př́ležitost nabývati vzdělání a prohlubovati je na základě vědeckém, aby bylo docíleno duševního i mravního povzneseni lidu československého“. Toto vzdělání mělo být poskytováno v patřičné hloubce, v souladu s nejnovějšími vědeckými poznatky a mělo vést k samostatnému kritickému myšlení. Vedle blíže nespecifikované široké veřejnosti cílilo působení Extenzí především na učitele škol nižších stupňů. Stanovy rozlišovaly několik typů přednášek a kurzů, které měly být pořádány, a další prostředky veřejného působení: 1) „Souvislé učební běhy“v ví́dlech místních extenzí (tedy v Praze, Brně a Bratislavě), které měly poskytnout pokud možno plný přehled o určitém oboru a mohly být rozvrženy i do několika let. 2) „Soustavné cykly přednášek a výkladư“ pojednávající o dílčích odborných problémech a pořádané vedle sídel extenzí také v dalších lokalitách. 3) „Jednotlivé přednášky“ konané kdekoli v rámci republiky. 4) Kroužky nebo semináře pro praktickou výuku organizované ve formě odpovídající univerzitním seminářům. 5) Další formy popularizace vědeckého poznání podle potřeby např́klad osvětové výstavy nebo vydávání publikací (obojí bylo posléze opravdu využito).

Extenze oficiálně sestávala ze „tři samostatných mistních vysokoškolských Extenzi" sídlících v Praze, Brně a Bratislavě a sdružovala tamní školy „s vyučovací řeči československou“", resp. jejich jednotlivé světské fakulty. Stanovy zdůrazňovaly nutnost jejich součinnosti a shodu na programových záležitostech, „,aby Extense československých vysokých škol v republice Československé vystupovala navenek jako jednotné těleso, ovládané týmž duchem vědeckým a národním". V čele tř́ místních výborů, jejichž počet členů měl být úměrný celkovému počtu profesorů zastoupených fakult, ${ }^{91}$ stál předseda a tři místopředsedové. Tato tři předsednictva tvořila dohromady dvanáctičlenné zastupitelstvo československých Extenzí jako celku (samozřejmě s výjimkou německých škol), jež mělo za povinnost se alespoň jednou ročně sejít. Funkční období členů výborů i předsednictva bylo pětileté.

Přednášejícími v rámci Extenzí byli zaměstnanci vysokých škol od asistentů po profesory, př́ípadně jiní přední odborníci a zahraniční učenci. Vedle hostujících profesorů a zahraničních lektorů se tak zjevně počítalo s ukrajinskými a ruskými vědci v emigraci. Náklady na provoz Extenzí mělo hradit MŠANO vždy na základě programů a rozpočtů navržených

88 Tamtéž, nedatováno [počátek roku 1926].

89 AUK, AS UK, kart. 230, i. č. 3384, složka Lidové přednášky 1922-1923, MŠANO rektorátu UK, 18. 6. 1923, Praha.

90 Výklad v následujících třech odstavcích vychází ze znění stanov. Byly vydány tiskem jako samostatná brožura: Stanovy Extense vysokých škol československých v Republice československé, Praha 1926. Srov. také F. X. Halas, Extenze, s. 78n.

91 Počítalo se s jedním členem výboru vždy na deset řádných profesorů fakulty, a pokud jejich počet po poslední celé desítce přesáhl pět, pak ještě s jedním navíc. Když tedy na Přírodovědecké fakultě UK počátkem roku 1928 vzrostl počet profesorů natolik, že fakulta získala nárok na ještě jednoho zástupce ve výboru, byl do něj kooptován profesor této fakulty Viktor Janda. AUK, AS UK, kart. 230, i. č. 3384, zápisy ze schůzí výboru Extenze československých vysokých škol v Praze, 20. 3. 1928. 
jednotlivými místními extenzemi. Tento hlavní zdroj př́ijmů mohl být doplněn dary, vybíráním školného nebo př́spěvky spolupořadatelů. ${ }^{92}$

Ustavující schůze „Extense československých vysokých škol v Praze“ se konala 1. prosince 1926 za př́tomnosti 16 z 23 nově zvolených členů. Zahajoval ji a jednání vedl staronový předseda Jaroslav Bidlo, který byl na návrh prof. Eiselta z LF UK jednohlasně opět zvolen předsedou. Hned poté přijal výbor (rovněž jednomyslně) návrh národohospodáře Josefa Macka z ČVUT, aby byl v následujícím volebním období předsedou zástupce pražské techniky. Volbou tř́ místopředsedů se zastoupení UK a ČVUT v předsednictvu pak stalo paritním: 1) Theodor Kašpárek (ČVUT); 2) František Vavř́nek (PF UK); 3) Viktor Felber (ČVUT) ${ }^{93}$

O dva týdny později se výbor pražské extenze sešel znovu k běžnému jednání. Vzal na vědomí, že do čela brněnské extenze byl rovněž zvolen dosavadní předseda Vladimír Novák. Bidlovi tak zůstal zachován jeden ze dvou dosavadních partnerů pro jednání o zásadních otázkách všech tří místních extenzí. ${ }^{94} \mathrm{~V}$ př́ípadě bratislavské extenze volbu předsedy zkomplikovala kolize se stanovami způsobená malým počtem profesorů. ${ }^{95}$ Schůze předsedů všech tří místních extenzí se nakonec konala 3. dubna 1927 a na jejím programu byly mj. otázky výše subvencí, stanovení rozsahu kurzů a vydávání přednášek tiskem (viz níže). ${ }^{96}$

Staronový předseda pražské extenze hned v počátku svého dalšího funkčního období ve výboru inicioval diskusi o tom, jak co nejefektivněji upravit činnost v souladu se stanovami i faktickými aktuálními potřebami lidovýchovy. Zásadní otázkou bylo rozšǐření povědomí veřejnosti o aktivitách extenze. $V$ úvahu přicházela spolupráce s rozhlasem a populárně-naučnými časopisy (Česká osvěta, Naše doba), př́ípadně i reklama v biografech. Bidlo sám nadhodil také možnost obnovit vydávání popularizační série brožur (,Sbírka rozprav a studii' “), v nichž byly dříve některé přednášky otiskovány. ${ }^{97}$ Výbor pověřil Karla Domina, aby v této záležitosti oslovil nejprve nakladatelství J. Otto, tedy původního vydavatele uvedené ediční řady, a př́ípadně také další nakladatelství běžně spolupracující s vysokými školami ${ }^{98}$ konkrétně proběhlo neúspěšné jednání s Orbisem, ${ }^{99}$ jiné firmy na oslovení ani nereagovaly. Bidlo byl tedy pověren jednat s nakladatelstvím J. Otto na základě nabídky učiněné v květnu 1927.100

92 Jejich škála byla nejspíše dosti široká a pestrá. Na podnět vlastivědného pracovníka a historika Aloise Adamuse se tak na Bidla např. obrátila se žádostí o uspořádání přednášek Extenze Kulturní rada pro širší Ostravsko ,jako krajové ústředí veškeré osvětové a lidovýchovné práce na Ostravsku a jako vydržovatelka Lidové university Masarykovy“. MÚA, fond J. Bidlo, kart. 9, i. č. 816, Kulturní rada pro širší Ostravsko J. Bidlovi, 31. 1. 1922, Moravská Ostrava.

93 AUK, AS UK, kart. 230, i. č. 3384, zápisy ze schůzí výboru Extenze československých vysokých škol v Praze, 1. 12.1926 (volně vložený list).

94 Tamtéž, 16. 12. 1926.

95 Tamtéž, 3. 2. 1927.

96 Tamtéž, 21. 11. 1927.

97 Tamtéž, 16. 12. 1926.

98 Tamtéž, 3. 2. 1927.

99 Tamtéž, 21. 11. 1927. Následovala nejspíše schůzka pověřených redaktorů jednotlivých extenzí, jak je patrné z dopisu místopředsedy bratislavské extenze R. Horny. Ten se k jednání s nakladatelstvím J. Otto stavěl předem poměrně skepticky. MÚA, fond J. Bidlo, kart. 4, i. č. 243, R. Horna J. Bidlovi, 20. 11. 1927, Praha.

100 AUK, AS UK, kart. 230, i. č. 3384, zápisy ze schůzí výboru Extenze československých vysokých škol v Praze, 10. 1. 1928 . 
Nakonec se ale jako nejvýhodnější dodatečně ukázala nabídka Nakladatelství Jednoty československých matematiků a fyziků. ${ }^{101} \mathrm{~S}$ podmínkami souhlasily také výbory brněnské a bratislavské extenze; smlouva s nakladatelstvím zastoupeným Miroslavem Valouchem tak byla před polovinou roku 1928 podepsána. $Z$ každé místní extenze měli být jmenováni dva redaktoři, jeden pro „duchovědnou“ a druhý pro „př́rodovědeckou“ ediční řadu. Pražský výbor do těchto funkcí provizorně zvolil profesory Bidla a Kašpárka. ${ }^{102}$ Definitivně pak byl zvolen ještě před koncem téhož roku redaktorem I. řady Miloslav Hýsek, „,když předtím předseda prohlásil k návrhu prof. Lesného, že sám nehodlá redakce podržeti“. Theodor Kašpárek naopak zůstal i nadále redaktorem II. řady. ${ }^{103}$ Bidlo se ještě společně s oběma redaktory účastnil př́pravy pravidel, která měla být pro pražskou redakci ediční řady závazná. Vydávání Sbírky rozprav a studií mělo být finančně zajištěno zvláštní subvencí MŠANO, v první fázi ve výši $50000 \mathrm{Kč}$, kterou se skutečně podařilo získat. ${ }^{104}$

Ne všechny přednášky se pro otištění hodily, Vincenc Lesný např. odmítl kvůli tomu, že by nemohl doprovodit svůj text o Indii zamýšlenými obrazovými př́lohami. ${ }^{105}$ První svazky - spis Josefa Vítězslava Šimáka o svatém Václavu, ${ }^{106}$ jazykovědné fejetony Václava Ertla ${ }^{107}$ a práce o Sibiři T. Kašpárka ${ }^{108}$ - vyšly na přelomu let 1929 a 1930. Tisková př́íprava se sice mírně protahovala, protože JČMF „vzala na sebe tolik závazkỉ, že neni s to všem vyhověti ${ }^{\text {“ }}{ }^{109} \mathrm{i}$ tak ale publikace zejména pražské extenze rychle přibývaly. Členové výboru měli mít nárok na bezplatné získání těch, o něž si písemně požádají. Ostatní profesoři a docenti pak měli mít $25 \%$ slevu, pokud si publikace objednají př́imo v JČMF. ${ }^{110}$

Také spolupráce s rozhlasem se nakonec rozeběhla, byt' zprvu pomalu. Nejprve byl osloven doc. Ernest ze Zemědělského rozhlasu. ${ }^{111} \mathrm{Na}$ intenzitě ale nabralo snažení pražské extenze ve věci rozhlasových přednášek teprve ve chvíli, kdy se jejím partnerem v této oblasti stal Radiojournal. V roce 1933 byl zástupcem extenze $\mathrm{v}$,poradním sboru Radiojournalu pro věci programové" zvolen profesor Nachtikal. ${ }^{112}$ Extenze zároveň hledala širší domluvu s vysokými školami prostřednictvím akademických senátů a rektorské konference.

101 Tamtéž, 20. 3. 1928.

102 Tamtéž, 20. 6. 1928. Z korespondence s bratislavským profesorem R. Hornou je vidět, že měl Bidlo k jednání s nakladatelstvím Jednoty českých matematiků a fyziků poměrně volnou ruku: „Já souhlasím se vším, jenom bude-li nám zajištěno aspoň čtyři svazky ročně a bude-li moci redaktor každé Extenze, ovšem ve shodě s redaktory ostatními, sbírku samostatně říditi.“ MÚA, fond J. Bidlo, kart. 4, i. č. 243, R. Horna J. Bidlovi, 17. 10. 1928, Bratislava.

103 AUK, AS UK, kart. 230, i. č. 3384, zápisy ze schůzí výboru Extenze československých vysokých škol v Praze, 14. 12. 1928. T. Kašpárek ovšem poměrně záhy vážně onemocněl a 24. prosince 1930 zemřel. Během jeho nemoci až do zvolení nového redaktora měl dočasně obě řady na starosti M. Hýsek, než byl počátkem roku 1931 zvolen redaktorem př́rodovědné řady botanik Karel Kavina z ČVUT. Tamtéž, 19. 12. 1930, 20. 3. 1931.

104 Tamtéž, 18. 4. 1929.

105 MÚA, fond J. Bidlo, kart. 5, i. č. 383, V. Lesný J. Bidlovi, 2. 12. 1928, Praha.

106 Josef Vítězslav Šımák, O knižeti Václavovi, Praha 1929.

107 Václav ERTL, Časové úvahy o naši mateřštině, Praha 1929.

108 Theodor KAŠPÁREK, Sibiř, Praha 1930.

109 AUK, AS UK, kart. 230, i. č. 3384, zápisy ze schůzí výboru Extenze československých vysokých škol v Praze, 4. 2. 1930.

110 Ze záznamů je zřejmé, že jakýmsi neoficiálním prostředníkem ve vztahu k JČMF a jejímu nakladatelství byl fyzik František Nachtikal z ČVUT, který měl také na starost jednání ohledně exemplářủ pro vysokoškolské učitele. AUK, AS UK, kart. 230, i. č. 3384, zápisy ze schůzí výboru Extenze československých vysokých škol v Praze, 19. 12. 1930, 20. 3. 1931.

111 Tamtéž, 3. 2. 1927.

112 Tamtéž, 10. 11. 1933. 
V rámci výboru byla zvolena „,komise pro věci Radiojournalu“, jejíž členkou se stala rovněž M. Paulová (vedle profesorů Nachtikala, Hýska, Kaviny a Schneidera). ${ }^{113}$ Výbor se snažil zahrnout co nejvíce rozhlasových přednášek vysokoškolských pedagogů pod formální rámec extenze. ${ }^{114}$

Na úspěšné přednášky pro rakouské Čechy ${ }^{115}$ měla pražská extenze na Bidlův návrh navázat přednáškami pro menšinové školy v pohraničí. ${ }^{116}$ I tento typ přednášek měl pozitivní ohlas, jak o tom svědčí např. poděkování předsedovi Extenze zaslané ředitelem frýdlantské obecné a měšt’anské školy. ${ }^{117}$ Výbor rovněž schválil doporučení K. Domina, aby v takových př́padech Extenze zajistila honorář pro přednášející a na místních pořadatelích ponechala pouze režijní vydání. ${ }^{118}$ Dalším Bidlovým návrhem bylo přizvání ruských historiků z emigrace k přednáškám, které mělo svou paralelu i v jiných vědách (např. astronom František Nušl doporučil k realizaci přednášky astronoma Vsevoloda Viktoroviče Stratonova). ${ }^{119}$ Renomovaní externí přednášející nebyli úplnou výjimkou, Bidlo osobně úspěšně navrhl přednášky malíře, etnografa a slavisty Ludvíka Kuby, který o ně sám projevil zájem. ${ }^{120}$

I nový výbor extenze zvolený po vydání stanov byl nucen řešit poměr k Masarykovu lidovýchovnému ústavu, především zda vyučující na vysokých školách mají lidovýchovné přednášky zajišt'ovat pouze prostřednictvím extenze, nebo zda je mohou pořádající instituce oslovovat prímo. ${ }^{121}$ Pražským profesorům a docentům bylo v této věci Extenzí rozesláno 440 oběžníků, z nichž se 174 vrátilo se závazkem, že dotyční budou jako přednášející pro lidovýchovné přednášky používat výhradně prostřednictví Extenze. ${ }^{122}$ Nakonec došlo k domluvě: „Schváleno ujednání sekretářky s tajemnikem MLÚ drem Trnkou a př́pis MLÚ

113 Tamtéž, 5. 6. 1934.

114 Tamtéž, 13. 11. 1934.

115 Přednášky ve Vídni probíhaly i v letech 1927 a 1928, přičemž většinu nákladů hradila přímo pražská extenze; dodatečná subvence ministerstva zahraničních věcí pokryla necelou třetinu z nich. Tamtéž, 14. 12. 1928 a 18. 4. 1929.

116 Tamtéž, 3. 2. 1927.

117 „Ředitelství školy koná tímto svoji milou povinnost, aby Vám upřímně poděkovalo za vzácnou ochotu, již jste projevil nám - hraničářum - a vyhověl v plné míře našim přáním, abychom mohli důstojně oslaviti 78. narozeniny pana prezidenta. Pan docent Dr. Klíma zanechal tolik hlubokých dojmů v duších posluchačů, jichž bylo přes 500, takže naše prostorná tělocvična ani nestačila, že jsme byli v tento den opravdu zase jednou št’astni. Přednáška posílila nás tou měrou, že věříme v lepší budoucnost a jsme Vám proto neskonale vděčni. Naším přáním je, abychom se mohli opětně těšiti, že podobných št’astných chvilek dopřejete nám svou vzácnou blahovưlí zase a my se již předem na to těšíme." Jednalo se nejspíše o docenta pedagogiky Jiř́ho Václava Klímu. MÚA, fond J. Bidlo, kart. 9, i. č. 773, ředitel státní školy obecné a měštanské ve Frýdlantě v Čechách V. Václavík J. Bidlovi, 7. 3. 1928, Frýdlant.

118 AUK, AS UK, kart. 230, i. č. 3384, zápisy ze schůzí výboru Extenze československých vysokých škol v Praze, 3. 2. 1927. Odmítnuta byla naopak žádost českého odboru Okresního osvětového sboru v Litoměřicích, aby tam extenze uspořádala dvě německé přednášky českých profesorů „obsahu poučného pro tamější německou inteligenci jako poučení o české kultuře (Rádl, Ot. Fischer)“. Tamtéž, 14. 12. 1928.

119 AUK, AS UK, kart. 230, i. č. 3384, zápisy ze schůzí výboru Extenze československých vysokých škol v Praze, 21. 11. 1927.

120 Tamtéž, 14. 12. 1928.

121 Tamtéž, 21. 11. 1927.

122 Tamtéž, 20. 3. 1928. Reakcí na tento oběžník je např. dochovaný dopis sociologa Emanuela Chalupného, který v něm sděluje: „Děkuji zdvořile za laskavý př́ípis Váš i za oběžník dnes došlý. Dovolil bych si k němu ovšem poznámku, že pro soukromé docenty, kteří na vysokých školách přednášejí za nepatrné odškodnění nebo zdarma, nezdá se mi logickým prohlašovat přednášení v jiném prostředí za honorář menší než 200 Kč za nedůstojné. Akce univ[ersitní] extense má snad smysl pro pp. profesory nebo docenty honorované, ale ne pro bezplatné.“ MÚA, fond J. Bidlo, kart. 4, i. č. 266, E. Chalupný J. Bidlovi, 14. 3. 1928, Tábor. 
z 22. března 1928, kterým se MLÚ zavázal honorovati přednášky tak jako Extense a postupovati jí žádosti o přednášky po venkově. Extense pak svolila, aby sám př́mo vyjednával o prednášky v Praze s vysokoškolskými profesory. Kvůli extensní statistice budou ji tyto přednášky hlášeny vždy na konci roku. Usneseno oznámiti tuto dohodu přiležitostně všem členům vys[okých] škol."123 K dalšímu jednání o užší spolupráci MLÚ s Extenzemi pak došlo v polovině 30. let, přičemž pražská extenze (i oslovované fakulty UK a ČVUT) byla vưči těmto plánům nejopatrnější. ${ }^{124}$

MLÚ také oslovil pražský výbor s pozváním k účasti na Výstavě soudobé kultury v Brně v roce 1928 a víceméně paralelně probíhající Výstavě lidové výchovy konané v Městské knihovně v souvislosti s připravovaným Sjezdem lidovýchovných pracovníků. Na jednáních s MLÚ zastupoval pražskou extenzi místopředseda prof. Felber, který se k účasti všech tř́ místních extenzí na obou výstavách stavěl velmi pozitivně. Výbor jeho doporučení přijal a nabídl brněnské extenzi, aby příslušné přípravy pro Výstavu soudobé kultury zajistili její zástupci. M. Paulová připravila první návrh exponátů, které měly pražskou extenzi na výstavách představit. Jednalo se o: ,a) ukázky plakátů; b) sylabů; c) publikace (I. Ročenku, Sbírku přednášek a rozprav a II. Ročenku, přehled činnosti za 25 let trvání Extense, kterou sekretářka sestavi); d) čtyři diagramy“. Zatímco Bidlo byl spolu s profesory Felberem a Nachtikalem počátkem roku 1928 zvolen do „výstavní komise“, Paulovou společně s Felberem jmenoval výbor zástupci pro jednání s MLÚ o přípravách výstav. ${ }^{125}$ O dva měsíce později mohla tajemnice výboru s uspokojením konstatovat, že zpracování dvou velkoformátových ,kartogramư“ se ujal kreslír Vojenského geografického ústavu Jiří Sádlo, a také na publikaci se pracuje. Výbor rozhodl, že si pro účely výstavy nechá pořídit skupinové foto. ${ }^{126}$

Na výstavu byly prríslušné podklady včas dodány, ${ }^{127}$ během jejího trvání však stále ještě neskončily práce na jubilejním spisu, protože se čekalo na statistické údaje o bratislavské extenzi. Výbor i tak přiznal v souvislosti s oběma výstavami M. Paulové odměnu ve výši 700 Kč. ${ }^{128}$ Co se týká samotného tisku publikace, byl zajištěn mimořádnou subvencí MŠANO ve výši 3759 Kč. ${ }^{129}$

Více než padesátistránková brožura nakonec vyšla s vročením 1928. Pasáž o brněnské extenzi byla napsána tamním tajemníkem a kvestorem Masarykovy univerzity v jedné osobě Janem Opravilem, pasáž o bratislavské extenzi napsal předseda jejího výboru právní historik Richard Horna. Hlavním autorem ale byla M. Paulová. Jejím podílem nebylo jen

123 AUK, AS UK, kart. 230, i. č. 3384, zápisy ze schůzí výboru Extenze československých vysokých škol v Praze, 10. 7. 1928.

124 Tamtéž, 11. 3. 1935, 23. 10. 1935 a 17. 6. 1936.

125 Tamtéž, 21. 11. 1927 a 10.1. 1928.

126 Tamtéž, 20. 3. 1928.

127 Podle tištěného katalogu obsahovala vitrína věnovaná Extenzím, jež zde byly vnímány jako jedna celostátní organizace, fotografii T. G. Masaryka jako prvního přednášejícího po vzniku extenzí, sylaby přednášek, diplom z mezinárodního lidovýchovného kongresu v Miláně v r. 1926, ukázky publikací a plakátů, grafy shrnující účast na přednáškách, fotografie předsedů a současného výboru. Vitrína byla umístěna v prostorách, kde byly prezentovány i další vysokoškolské instituce. Bidlo sám byl na výstavě zastoupen ještě ukázkou rukopisu (společně s rukopisy J. Golla, J. Pekaře, J. Šusty, V. Novotného a K. Krofty) v části věnované dějepisu. Výstava soudobé kultury v ČSR, Brno 1928, s. 221, 184.

128 AUK, AS UK, kart. 230, i. č. 3384, zápisy ze schůzí výboru Extenze československých vysokých škol v Praze, 10. 7. 1928.

129 Tamtéž, 18. 4. 1929. 
dvacetistránkové pojednání o minulosti extenze a o pražské extenzi zvláště, svědčící mj. o práci s prameny z univerzitního archivu a osobní účasti v aktivitách extenze $\mathrm{v}$ posledních letech, ale i celková redakce a sestavení části podrobných statistických př́loh zahrnujících více než třetinu publikace. $\mathrm{Z}$ nich ,je patrno, že za 30 let (1898-1928) bylo vykonáno Extensí pražskou 6589 přednášek, jež navštívilo 1,002.580 posluchačư “. ${ }^{130}$

Pražská „Výstava lidové výchovy“ byla opakovaně odkládána, nejprve na prosinec 1928, poté na jaro 1929.131 Měla se konat ve dnech 16.-26. května na novém výstavišti Pražských vzorkových veletrhů a také v tomto př́ípadě mělo její konání doprovázet vydání výstavního katalogu. Souvisejícími pracemi byla pověřena opět M. Paulová. ${ }^{132}$ Po jejich úspěšném vykonání a po skončení výstavy výbor navrhl jí i F. Kaprálkovi mimořádnou odměnu, která zohledňovala také povinnosti spojené se stěhováním kanceláře Extenze. V souvislosti s dostavbou nové budovy Filozofické fakulty UK totiž došlo ke změně oficiálního sídla pražské extenze, která se tak v prosinci 1929 z Veleslavínovy ulice přesunula na Smetanovo náměstí (dnešní náměstí Jana Palacha). ${ }^{133}$ Nová kancelář byla o dva roky později vybavena novým mobiliářem. ${ }^{134}$

Extenze nemohla opomenout ani oslavy 80. narozenin T. G. Masaryka. Jaroslav Bidlo při této př́ležitosti využil svého postavení ve Slovanském ústavu (byl jedním ze tř́ členů výboru I. odboru, tedy kulturního) a navrhl, aby se extenze připojila $\mathrm{k}$ přednáškovému cyklu připravenému právě Slovanským ústavem. Profesor Hýsek při té př́ležitosti projevil zájem připojit se s přednáškou o Masarykovi a literatuře. ${ }^{135}$ Svou přednášku ale nakonec neuveřejnil v publikaci založené na přednáškovém cyklu, ,,ycházeje s hlediska, že jeho přednáška nebyla v cyklu Slovanského ústavu, nýbrž v přednáškách extensních“. ${ }^{136}$ Snad to bylo Bidlovo neformální prostřednictví, jež se snažilo nadále připoutat $\mathrm{k}$ sobě Extenzi a Slovanský ústav, když byl její výbor na konci roku 1931 vyzván, aby zvolil „,delegáta do poradního sboru čsl. nepolitických spolki̊ a svazů kulturních, který Slovanský ústav hodlá utvořiti“. Stal se jím nový předseda pražské extenze profesor Felber. 137

Nejvýznamnějším počinem pražské extenze v oblasti mezinárodní spolupráce za Bidlova předsednictví byla nepochybně účast na světovém kongresu Mezinárodního svazu pro lidovou výchovu v srpnu 1929 v Cambridge, kde ji zastupoval člen výboru, národohospodář Josef Macek. Jeho dojmy byly mimořádně dobré a průběh kongresu podle jeho zprávy podané výboru potvrdil, jak vysokému zájmu se problematika lidové výchovy ve světě (a ve Velké Británii zvláště) těší. V reorganizovaném výboru Mezinárodního svazu získala v průběhu kongresu Československá republika jedno místo, jež bylo obsazeno velvyslancem v Británii Janem Masarykem. Z uvedené reorganizace vyplynula také pro instituce jednotlivých států nutnost vytvořit ,státní skupinu“, tedy obdobu dnešních národních komitétů pro jednotlivé vědecké oblasti, která by volila členy do širšího výboru Svazu. Iniciativy

130 Tamtéž, 14. 12. 1928.

131 Tamtéž, 10. 7. 1928, 14. 12. 1928.

132 Tamtéž, 18. 4. 1929.

133 Tamtéž, 4. 2. 1930.

134 Tamtéž, 20. 1. 1932.

135 Tamtéž, 4. 2. 1930.

136 Miloš Weingart, Předmluva, in: týž (ed.), Sborník přednášek o T. G. Masarykovi, Praha 1931, (= Přednášky Slovanského ústavu v Praze, sv. 1), s. VIII.

137 AUK, AS UK, kart. 230, i. č. 3384, zápisy ze schůzí výboru Extenze československých vysokých škol v Praze, 20. 1. 1932 . 
se chopil MLÚ, jenž pro její jednání dal k dispozici svou kancelář. Pražskou extenzi měla ve „státní skupině“ zastupovat M. Paulová - počítalo se i s jejím vysláním na prŕšší kongres - a delegátem pro širší výbor Svazu byl zvolen anglista Vilém Mathesius, snad právě s ohledem na dobrou znalost jednacího jazyka. Jednalo se ovšem prozatím o funkci spíše hypotetickou, protože byla vázána na souhlas ostatních místních extenzí. ${ }^{138}$ To ukázala i reakce brněnské extenze, která si toto místo nárokovala pro svého předsedu V. Nováka, což bylo vzhledem k jeho postavení a dlouholetým vazbám na britské př́rodovědce zcela pochopitelné. ${ }^{139} \mathrm{~V}$ otázce členského prŕíspěvku extenze v Mezinárodním svazu pro lidovou výchovu jí vyšlo MŠANO rychle vstříc poskytnutím mimořádné dotace ve výši 10000 Kč, jež byla ovšem určena také k pokrytí mimořádných nákladů na přednášky na venkově. ${ }^{140}$

Prestižní záležitostí se mělo stát rovněž uspořádání př̌ednášek předsedy Mezinárodní asociace pro výchovu dospělých (World Association for Adult Education) prof. Alberta Mansbridge, k němuž byla počátkem roku 1931 vyzvána ministerstvem zahraničí v součinnosti s Univerzitou Karlovou. ${ }^{141}$ Milada Paulová považovala za iniciátory pozvání zprostředkovaného Janem Masarykem profesory FF UK Viléma Mathesia a Jana Blahoslava Kozáka. ${ }^{142}$ Sám Bidlo se s Albertem Mansbridgem osobně setkal již během jeho pobytu v Československu na přelomu let 1920 a $1921 .^{143}$

Od druhé poloviny 20. let sílily tlaky zvnějšku, aby Filozofická fakulta UK zř́dila profesuru lidové výchovy. Kromě konkrétních žadatelů (ministerský tajemník MŠANO Antonín Matula) směřovaly tyto podněty od Masarykova lidovýchovného ústavu. Fakulta se záměrům zprvu bránila, přičemž závěry komisí svolávaných - za Bidlova členství - pro posouzení těchto plánů vyzněly vždy odmítavě s poukazem na to, že lidová výchova představuje pouze jeden výsek z pedagogiky. ${ }^{144}$

Působení v Extenzi svedlo Bidla dohromady s řadou lidí působících v oblasti lidovýchovy v regionech. S otázkou lektorátu lidovýchovy na FF UK souvisí příklad učitele, osvětového pracovníka a průkopníka skautingu PhDr. Jana Hořejšího (1885-1957) působícího počátkem třicátých let na gymnáziu v Hradci Králové. U Bidla tehdy hledal podporu ve svých snahách o získání lektorátu, resp. o habilitaci v oboru pedagogiky na FF UK, jejímž základem se měla stát monografie Lidová výchova a její regionální studium (1931), i v úsilí o získání místa v Praze či alespoň v její blízkosti. ${ }^{145}$ Komise, v níž byl referentem v této

138 Tamtéž, 18. 4. 1929 a 4. 2. 1930.

139 Tamtéž, 19. 12. 1930 a 20. 3. 1931. Pražská extenze poté bez připomínek proplácela částku 137 Kč na jeho cestu do Vídně, kde zastupoval československé extenze na „schůzi Světového svazu pro lidovýchovu“. AUK, AS UK, kart. 230, i. č. 3384, zápisy ze schůzí výboru Extenze československých vysokých škol v Praze, 20. 2. 1931.

140 Tamtéž, 19. 12. 1930.

141 Tamtéž, 20. 3. 1931.

142 D. Brádlerová - J. HÁlek (edd.), Jaroslav Bidlo - Milada Paulová. Střet generací?, s. 392.

143 „Dear Dr. Bidlo, It was a great pleasure to meet you and to have the chance of talking to you on the premises of so ancient a University [!]. // I should like to send you a copy of the Bulletin of the World Association for Adult Education dealing with Czecho-Slovakia, and to assure you that at all times I shall be happy to send you any information you may like to have. // As I promised, I will send you in due course, although it will be some time yet, the Report of the Royal Commission on the Universities of Oxford and Cambridge. // I wish you, your University and your country continued success. “MÚA, f. J. Bidlo, kart. 6, i. č. 407, A. Mansbridge J. Bidlovi, 27. 1. 1921, Londýn.

144 AUK, FF UK, kart. 75, i. č. 846, Lektorát lidové výchovy.

145 MÚA, fond J. Bidlo, doplnit, i. č. 244, kart. 4, i. č. 244, J. Hořejší J. Bidlovi, 24. 2. a 2. 4. 1931, Hradec Králové. Srov. také tamtéž, kart. 5, i. č. 297, O. Kádner J. Bidlovi, 29. 4. 1931, s. 1. 
záležitosti právě J. Bidlo a zasedal v ní spolu s M. Hýskem, J. B. Kozákem, B. Foustkou a O. Kádnerem, doporučila zrrídit nejprve lektorát lidové výchovy, a osvědčí-li se, umožnit žadateli následně habilitaci z pedagogiky se zvláštním zřetelem k lidovýchově.

V obsáhlém odůvodnění formulovaném Bidlem je zřízení lektorátu lidové výchovy dáváno do prímého kontextu s extenzemi, na něž je nahlíženo i kritickým okem: ,Vysoké školy však nebyly fyzicky s to, aby podržely vedení lidovýchovného proudu, z čehož však plyne nebezpečí, aby jeho vedení se nedostalo do rukou lidí nepovolaných, tj. hlavně nemajících dostatek smyslu vědeckého a usilujicích učiniti z výtěžků vědeckého bádání prostredky snah osobnich nebo stavovských. Je tudiž potřebí, aby jak výchova dětí a dospívající mládeže, tak $i$ vzdělávání dospělých bylo založeno a řizeno z vědeckých základů a vědeckými metodami, aby se na základě životní praxe s jejími světlými i temnými stránkami vytvořila přiměrená teorie, ba přimo věda, věda ovšem praktická. Zde nastává nepodněcovatelný úkol filosofickým fakultám, aby vytváreni této vědy přijaly do svého programu, zvláště proto, že $v$ demokratických státech se hlási obzvláštni potřeba, aby nižši vrstvy lidové, které svým hlasovacím právem namnoze rozhoduji o osobách řídicich osudy států, byly povznášeny $k$ vyšši vzdělanosti. “ Zřízení lektorátu tak bylo bráno jako pokus, který by v př́ípadě úspěchu mohl vést až $\mathrm{k}$ plnohodnotné profesuře. ${ }^{146}$

\section{Bidlův odchod z vedení pražské extenze a poslední roky Milady Paulové ve funkci tajemnice}

V souladu se stanovami Extenzí zvolily do začátku akademického roku 1931/1932 profesorské sbory pražských fakult své (staro)nové zástupce do pražského výboru. Termín ustavující schůze byl ze září posunut na 26. ř́ina 1931, protože právnická fakulta omylem zvolila původně jen jednoho zástupce a čekalo se, až dovolí druhého. Bidlo jakožto odstupující předseda schůzi zahájil a řídil až do volby nového předsedy, jímž se stal dosavadní místopředseda Viktor Felber z ČVUT. ${ }^{147}$ Zásada postulovaná po přijetí nových stanov v r. 1926, aby se na postu předsedy střídali po jednotlivých funkčních obdobích zástupci univerzity a techniky, byla dodržena - domníváme se, že vědomě - nový předseda nicméně zvítězil ve volbách se dvěma (formálními) protikandidáty. Byli jimi slavista Miloš Weingart z FF UK a botanik Karel Kavina z ČVUT. ${ }^{148}$ Místopředsedy se nakonec stali profesoři Hýsek, Kavina a Domin.

Kromě toho, že nový předseda poděkoval „,v̌̌elými slovy odstupujícímu předsedovi prof. Bidlovi za dlouholetou a obétavou činnost", navrhl indolog Vincenc Lesný, aby mu byla u ministerstva školství vyjednána „čestná odměna“ 15000 Kč. Výbor návrh jednomyslně

146 AUK, FF UK, kart. 26, i. č. 296, osobní spis Jana Hořejšího, Zpráva komise o žádosti Dra Jana Hořejšího za lektorát lidovýchovy, 18. 6. 1931, Praha. Jan Hořejší na FF UK působil jako lektor, přednášející kromě samotné lidové výchovy také řečnictví a techniku sebevzdělávání, až do začátku 50. let.

147 AUK, AS UK, kart. 230, i. č. 3384, zápisy ze schůzí výboru Extenze československých vysokých škol v Praze, 26. 10. 1931. O záležitosti s PF UK také D. BrÁdlerová - J. HÁleK (edd.), Jaroslav Bidlo - Milada Paulová. Střet generací?, s. 398.

148 Původně se patrně počítalo také s kandidaturou Františka Vavřínka z Právnické fakulty UK. D. BRÁDLEROVÁ J. HÁlek (edd.), Jaroslav Bidlo - Milada Paulová. Střet generací?, s. 398. 
přijal. ${ }^{149}$ Vzhledem $\mathrm{k}$ tomu, že právě probíhaly škrty v důsledku hospodářské krize a samotné Extenzi byla významně snížena dotace, odložilo ministerstvo tuto záležitost ,na vhodnějši dobu“ ${ }^{150}$ Sama Extenze byla nucena přistoupit k úsporným opatřením - omezit počet přednášek, rezignovat na tisk syllabů a podniknout ještě další kroky. Nesouhlas zapisovatelky s návrhy ministerstva, který s ní vzhledem $\mathrm{k}$ výslednému usnesení zjevně sdílel i výbor, z protokolu o schůzi přímo čiší: „V prípise [MŠANO] se současně žádá, aby se stalo predmětem úvahy, jak by se daly docíliti úspory vodmènách za funkce administrativní..." Podle mínění výboru „redukce odměn, beztak poměrně malých, za práce administrativní není dosud odiovodněna". 151

Prof. Felber se vzhledem $\mathrm{k}$ hospodářské krizi a všeobecné úsporné politice neujímal vedení pražské extenze ve štastné době. Odstupujícímu předsedovi je nutné přičíst $\mathrm{k}$ dobru, že její finance byly $\mathrm{v}$ této době $\mathrm{v}$ dobrém stavu a stávající rezerva mohla výpadek př́imů částečně pokrýt. ${ }^{152}$ Záhy po převzetí funkce absolvoval Felber jednání na ministerstvu školství ohledně subvence, která měla být krácena o 30-50\%. Šetřilo se i v př́ípadě Sbírky přednášek a rozprav, kde měly být na nejnutnější minimum omezeny obrazové př́lohy a podřízeny srozumitelnosti samotného textu. ${ }^{153} \mathrm{~V}$ roce 1932 získala pražská extenze - po mnoha urgencích na ministerstvu školství a financí a s podporou rektorské konference subvenci pouze ve výši 25000 Kč. Na situaci reagovala omezením počtu přednášek a úplným dočasným zrušením (na časovou dotaci náročných) semestrálních přednášek. Vedle toho byly také sníženy finanční prríspěvky na mimopražské přednášky a byl zastaven tisk sylabů a plakátů. ${ }^{154}$ Výška finanční subvence měla zůstat stejná i v r. 1933 (nakonec byla dokonce ještě o $2000 \mathrm{Kč} \mathrm{snižena}{ }^{155}$ ). Jednatelce nezbylo, než v rámci zprávy podávané výboru na konci roku 1933 konstatovat, že ,snižením ročního př́spěvku ministerstva školství ze 70.000 Kč na 25.000 Kč byla těžce ochromena činnost Extense“. 156

$\mathrm{Na}$ funkci předsedy Extenze rezignoval V. Felber již 24. ř́jina 1932, stejně jako na členství ve výboru. Jeho povinnosti na přechodnou dobu převzal další ze zástupců ČVUT, matematik Josef Kounovský, než byl řádnou volbou pro zbytek funkčního období zvolen prof. František Nachtikal. ${ }^{157}$ Ještě před volbou nového výboru ukončila svou činnost v Extenzi také Milada Paulová - po jmenování mimořádnou profesorkou rezignovala na funkci sekretářky Extenze vysokých škol pražských k 1. lednu 1936. ${ }^{158}$ Jejím nástupcem se stal docent FF UK Jan Blahoslav Čapek. ${ }^{159}$

\footnotetext{
149 AUK, AS UK, kart. 230, i. č. 3384, zápisy ze schůzí výboru Extenze československých vysokých škol v Praze, 26. 10. 1931.

150 Tamtéž, 20. 1. 1932.

151 Tamtéž, 4. 11. 1932.

152 Srov. účetní zprávu podávanou na konci r. 1932. AUK, AS UK, kart. 230, i. č. 3384, zápisy ze schůzí výboru Extenze československých vysokých škol v Praze, 4. 11. 1932.

153 Tamtéž, 20. 1. 1932.

154 Tamtéž, 4. 11. 1932.

155 Tamtéž, 5. 6. 1934.

156 Tamtéž, 10. 11. 1933.

157 Tamtéž, 10. 11. 1933.

158 Tamtéž, 23. 10. 1935.

159 Tamtéž, 17. 6. 1936.
} 


\title{
Epilog
}

V době, kdy Milada Paulová končila na postu sekretářky pražské extenze, bylo postavení této organizace značně odlišné od situace, kdy se této funkce ujímala. Extenze v Brně a v Bratislavě už byly etablovanými institucemi, a přestože tvořily společně s pražskou formálně jeden celek, v praktickém rozhodování a činnosti fungovaly do velké míry nezávisle. Dobře to ilustruje poměr k Masarykovu lidovýchovnému ústavu, vǔči němuž panovala největší nedůvěra právě v Praze. Na poslední schůzi, které se $M$. Paulová účastnila jako tajemnice výboru, byl dlouze projednáván právě poměr $\mathrm{k}$ MLÚ, přičemž zastánců bližší spolupráce přibývalo. Protože se ale také jednalo o jednu z posledních schůzí během funkčního období výboru, rozhodnutí mělo být ponecháno až na (staro)nově zvolených členech. Jeden z dlouholetých spolupracovníků Extenzí, slavista Miloš Weingart, přitom konstatoval, že právě noví členové výboru by měli „uvažovati vůbec o hledání nových cest pro Extensi, poněvadž její tradiční zpưsob činnosti prednáškové se prežil"“. ${ }^{160}$ Toto hledání však už probíhalo bez většiny osob, které zásadně ovlivňovaly fungování Extenzí a jejich proměny po 28. ř́jinu 1918.

Podnětem ke vzniku této studie byla v první fázi snaha doplnit bílá místa $\mathrm{v}$ odborných životopisech Jaroslava Bidla a Milady Paulové, kam činnost v Extenzích vzhledem ke svému rozsahu a intenzitě nepochybně patří. Vzhledem $\mathrm{k}$ tomu, že dějiny pražské extenze zvláště pro meziválečné období de facto nejsou vůbec zpracovány, bylo nutné si ve výkladu někdy všímat také obecnější problematiky, proto může studie představovat i určité vodítko pro badatele, kteř́ by zamýšleli zpracovat dějiny Extenzí soustavněji a komplexněji. Bidlo představoval od druhého desetiletí 20 . století jednu z rozhodujících osob v rámci vedení pražské extenze a několik let po vzniku ČSR stál po celou jednu dekádu v jejím čele. Během jeho předsednictví i nadále (až do dosažení vlastní mimořádné profesury) byla hlavní výkonnou administrativní silou výboru pražské extenze, zodpovědnou do značné míry také za zajištění odborného programu přednášek, Milada Paulová. Její působení lze chápat také jako součást obecnějších emancipačních snah žen v české, resp. československé vědě v pramenech jsme zatím nenalezli žádné zmínky o tom, že by její odborné kompetence pro výkon této funkce někdo otevřeně zpochybňoval.

\section{DAS WIRKEN VON JAROSLAV BIDLO UND MILADA PAULOVÁ IN DER PRAGER UNIVERSITÄTSEXTENSION}

\author{
ZUSAMMENFASSUNG
}

Ein verbreitetes Phänomen an den europäischen und nordamerikanischen Schulen in der zweiten Hälfte des 19. Jahrhunderts waren Bestrebungen, höhere Bildung unter die breiten Schichten der Öffentlichkeit zu verbreiten. Die böhmische Karl-Ferdinands-Universität, die sich in dieser Frage insbesondere britische Universitäten zum Vorbild nahm, begann auf diese Weise ab 1899, die Öffentlichkeit regelmäßig anzusprechen, später (ab 1908) erfolgte dies in enger Zusammenarbeit mit der Tschechischen Technischen Hochschule. Die organisatorischen

160 Tamtéž, 23. 10. 1935. 
Angelegenheiten besorgte der Ausschuss für Volksbildungs-Vorträge der tschechischen Prager Hochschulen, den man nach britischem Muster inoffiziell „Extension“ bezeichnete. Die neuen Statuten übernahmen diesen Terminus 1926 auch in die offizielle Bezeichnung (Extenze českých vysokých škol pražských - „Extension der Prager tschechischen Hochschulen“). Zu dieser Zeit arbeiteten die Prager Hochschulen auf diesem Gebiet bereits mit den neugegründeten Universitäten in Brno (Brünn) und Bratislava zusammen. Eine bedeutende Rolle in der Organisation der Prager Universitätsextension spielten die Vertreter der historischen Slawistik Jaroslav Bidlo (1868-1937) und seine Schülerin Milada Paulová (1891-1970). Bidlo schloss sich der Tätigkeit der Extension bereits kurz nach seiner Habilitation an (sein in diesem Rahmen ältestbelegter Vortrag datiert 1902) und war ab 1911 zwei Jahrzehnte lang ununterbrochen als Mitglied des aus Vertretern der einzelnen Fakultäten der Universität und des Technikums bestehenden Ausschusses der Prager Extension tätig. Im Jahre 1921 wurde er zu seinem Vorsitzenden gewählt, dieses Amt hatte er zehn Jahre lang bis 1931 inne. In der Geschichte der Extension handelt es sich um einen Zeitraum stürmischer Entwicklung, in welchem man sich mit einer beträchtlichen Veränderung der Volksbildungsbewegung abfinden, ihren Platz unter der Konkurrenz der neu entstandenen Institutionen (namentlich des Masaryk-Volksbildungsinstituts) neu definieren sowie neue Wege finden musste, die Öffentlichkeit anzusprechen, beispielsweise mittels Rundfunkvorträgen.

Die praktische Organisierung der Vortragszyklen, die Kommunikation mit den Referenten und Mitausrichtern und die Leitung der damit zusammenhängenden Verwaltung lag in den Händen von Milada Paulová, der Sekretärin der Prager Extension. Die Zusammenarbeit mit ihrem Lehrer Jaroslav Bidlo auf dieser Ebene rundet unser bisheriges Bild von ihren beruflichen wie persönlichen Beziehungen deutlich ab und zeugt auch von der Stellung der historischen Slawistik als Fach, dessen Bedeutung und Unterstützung staatlicherseits nach der Gründung der Tschechoslowakischen Republik rapide gewachsen war. Vorliegende Studie fußt einerseits auf amtlichen Quellen aus dem Bestand des Akademischen Senats der Karlsuniversität, der sich in ihrem Archiv befindet (Archiv Univerzity Karlovy), andererseits auf Quellen aus dem Bestand der Personalunterlagen J. Bidlos und M. Paulovás im Masaryk-Institut und Archiv der Akademie der Wissenschaften der Tschechischen Republik (Masarykův ústav a Archiv Akademie věd České republiky).

(C) Deutsche Übersetzung Wolf B. Oerter

PhDr. Daniela Brádlerová, Ph.D.

Masarykův ústav a Archiv $A V \check{C} R$, v.v. i., Praha

bradlerova@mua.cas.cz

PhDr. Marek Ďurčanský, Ph.D.

Ústav dějin a archiv Univerzity Karlovy

marek.durcansky@ruk.cuni.cz

\section{Grantová podpora:}

Tato studie vznikla jako výstup z projektu „,Jaroslav Bidlo a Milada Paulová: zakladatelské osobnosti historické slavistiky v kontextu vývoje české vědy “, podpořeného Grantovou agenturou České republiky (grant č. 18-20451S, řešitel Marek Durčanský). 